\title{
Observations of storm-induced mixing and Gulf Stream Ring incursion over the southern flank of Georges Bank: Winter and summer 1997
}

\author{
Craig M. Lee ${ }^{1}$ and Kenneth H. Brink ${ }^{2}$ \\ Received 8 August 2009; revised 1 February 2010; accepted 18 February 2010; published 7 August 2010.
}

[1] High-resolution hydrographic measurements collected along the southern edge of Georges Bank during March and June-July 1997 focused on characterizing processes that drive fluxes of material between the slope and bank. Wintertime sampling characterized changes driven by a strong storm. A Scotian Shelf crossover event produced a ribbon of anomalously fresh water along the bank's southern flank that was diluted during the storm. Comparison of prestorm and poststorm sections shows that over the bank changes in heat and salt inventories are consistent with those expected solely from local surface fluxes. In deeper waters, advective effects, likely associated with frontal motion and eddies, are clearly important. Summertime surveys resolve the development of a massive intrusion of Gulf Stream-like waters onto the bank. East of the intrusion, a thin extrusion of bank water is drawn outward by the developing ring, exporting fresher water at a rate of about $7 \times 10^{4} \mathrm{~m}^{3} / \mathrm{s}$. A large-amplitude Gulf Stream meander appears to initiate the extrusion, but it quickly evolves, near the bank edge, into a warm core ring. Ring water intrudes to approximately the $80 \mathrm{~m}$ isobath, $40 \mathrm{~km}$ inshore from the bank edge. The intrusion process seems analogous to the development of Gulf Stream shingles (a hydrodynamic instability) in the South Atlantic Bight. It appears that, once the intruded water is established on the bank, it remains there and dissipates in place. Although the intrusion is an extremely dramatic event, it is probably not actually a major contributor to shelf edge exchanges over a seasonal time scale.

Citation: Lee, C. M., and K. H. Brink (2010), Observations of storm-induced mixing and Gulf Stream Ring incursion over the southern flank of Georges Bank: Winter and summer 1997, J. Geophys. Res., 115, C08008, doi:10.1029/2009JC005706.

\section{Introduction}

[2] Georges Bank (Figure 1) is an area of shallow (20$100 \mathrm{~m}$ ) water that separates the Gulf of Maine from the open Atlantic Ocean. Historically, it is one of the world's great fisheries [e.g., Backus and Bourne, 1987] and has consequently received an unusual degree of scientific attention. The area is dominated by strong tidal currents because of the Bay of Fundy-Gulf of Maine $\mathrm{M}_{2}(12.42 \mathrm{~h})$ tidal nearresonance [Brown and Moody, 1987]. These tidal currents, in turn, cause a range of secondary effects, the most dramatic of which is perhaps the mid-bank surface-to-bottom homogenization that occurs year-round because of mixing in the turbulent bottom boundary layer [e.g., Flagg, 1987]. In addition, Georges Bank is embedded within a regional shelf circulation pattern, characterized by equatorward along-isobath flow around the bank and a shelf break front that separates fresher bank or shelf waters from saltier

\footnotetext{
${ }^{1}$ Applied Physics Laboratory, University of Washington, Seattle, Washington, USA.

${ }^{2}$ Department of Physical Oceanography, Woods Hole Oceanographic Institution, Woods Hole, Massachusettes, USA.

Copyright 2010 by the American Geophysical Union. 0148-0227/10/2009JC005706
}

oceanic waters. The two channels that border the bank (the Great South and Northeast channel) served as conduits for the northward transport of high-salinity slope waters into the Gulf of Maine, which also receives fresher inputs from the Scotian Shelf and riverine inflows [Brown and Beardsley, 1978]. The flow pattern around the bank never forms a truly closed loop, but the recirculation is strongest in the summertime [e.g., Brink et al., 2003]. The year-round shelf edge front is strongly affected by instabilities, offshore eddies, and wind-driven perturbations [e.g., Loder et al., 1998]. Further, tracer data demonstrate that the shelf break front is not impermeable: there are both onshore and especially offshore cross-frontal fluxes [Chapman et al., 1986].

[3] Upper ocean water masses here are most readily distinguished by their salinities. Waters on the bank have salinities representative of those in Mid-Atlantic Bight shelf waters, in the range of 33.2-33.4 in the winter and 32.5-33 in the summer [Flagg, 1987]. Fresher water $(<32)$ is often found east of the Northeast Channel over the Scotian Shelf and over Browns Bank in particular [Bisagni et al., 1996; Smith et al., 2003]. Saltier (35.2-35.4) slope water is found offshore between the bank and the Gulf Stream. Salty water is also found occasionally at depth west of our sampling area during the fall in the Great South Channel, near $69^{\circ} \mathrm{W}$ 


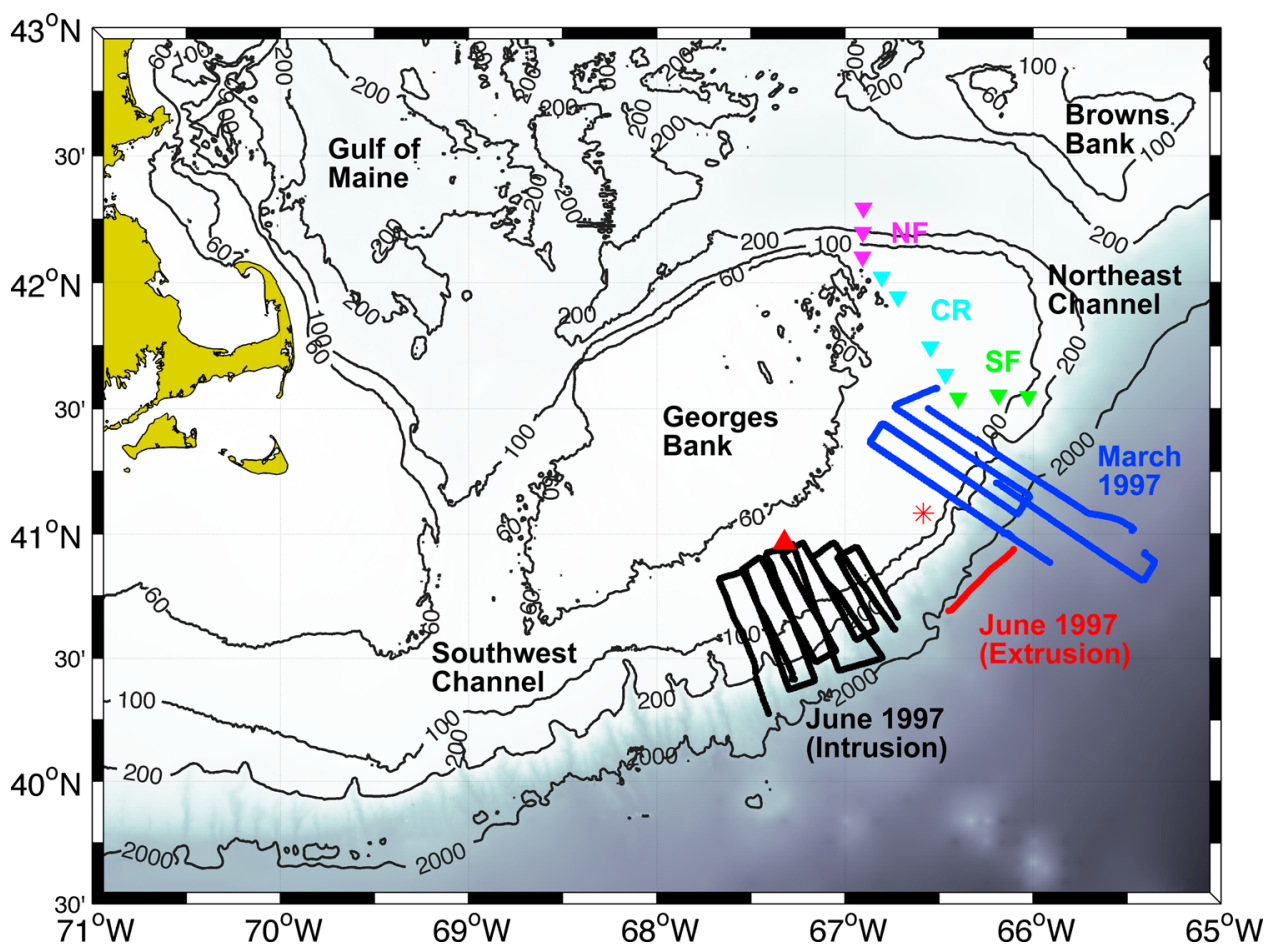

Figure 1. The Georges Bank study region. Contours mark the 60, 100, 200, and $2000 \mathrm{~m}$ isobaths. Black (June 1997 intrusion), red (June 1997 streamer), and blue (March 1997 prestorm and poststorm) lines mark specific surveys discussed within the text. Complete survey tracks for the winter and summer cruises are not shown. Pink (northern flank), light blue (crest), and green (southern flank) inverted triangles mark the location of CTD stations occupied by broadscale cruises conducted before and after the March 1997 SeaSoar cruise. A red asterisk marks NDBC meteorological buoy 44011, and a red triangle indicates the position of the GLOBEC south flank mooring.

[Mountain et al., 1989]. Higher salinities (>36) are sometimes found in the slope water in conjunction with warm core rings, which are energetic eddies that originate in the Gulf Stream itself [e.g., Joyce, 1991]. During the summertime, the bank is characterized by two frontal systems [e.g., Flagg, 1987]. Near the $60 \mathrm{~m}$ isobath is a tidal mixing front that separates vertically homogeneous waters from stratified, deeper waters. At the bottom, near the $100 \mathrm{~m}$ isobath (and tilting off-bank toward the surface) is a shelf break front that separates the fresher and saltier waters throughout the year. During the wintertime, all of the bank waters tend to be vertically homogeneous, so the tidal mixing front disappears or perhaps merges with the shelf break front.

[4] This physical background is the context for Georges Bank's high biological activity. The Global Ocean Ecosystem Dynamics (GLOBEC) program selected the area for intensive study because the causes of year-to-year natural variations in fish and zooplankton stocks were not well understood and because the bank's geographical position makes it a particularly sensitive place to study the effects of climate variations. GLOBEC is based on the underlying hypothesis that the biological variations are caused by physical processes (see Wiebe et al. [2002] for a good overview). During 1995, efforts focused on the role played by density stratification, while during 1997, the programmatic focus was on source, retention, and loss processes on the bank, with some emphasis on the southern flank, which abuts the deeper Atlantic waters [Beardsley et al., 2003].
The underlying idea motivating the present work is that organisms can be withdrawn from the bank (and so affect year-to-year population variations) due to winds, eddies, or frontal instabilities.

[5] We sought to carry out detailed characterizations of how Georges Bank southern flank water is exchanged between the bank and offshore. Particular questions included the volume of water transported by particular mechanisms, the locations and depths from which bank water was removed (hence, likelihood of removing biota), and the frequency of occurrence for a particular mechanism. Similarly, onshore transports can be biologically important in terms of zooplankton biomass and diversity [Cox and Wiebe, 1979], so we were also concerned with these as well. Our initial plan recognized the need to study frontal instabilities, wind forcing, and offshore eddy effects. Since offshore eddies tend to occur sporadically and without any obvious seasonal pattern, these were only to be addressed if they were encountered. What could be counted on was wind variability. Thus, we arranged a winter cruise to explore the effects of winds on cross-frontal exchanges and a summer cruise (when winds are much weaker [e.g., Brink et al., 2003]) to focus on frontal instabilities. If a warm core ring appeared during either season, it was to receive priority in sampling. In both seasons, the goal was to do repeated "radiator patterns" near the shelf edge, oriented so that ship lines (hence best resolution) most often ran in the crossisobath direction. The idea was to produce a resolved time 
series of three-dimensional spatial maps to characterize the process of interest.

\section{Data}

\subsection{In situ Measurements}

[6] Two cruises, on $R / V$ Oceanus from 2 to 12 March 1997 (Figure 1) and on $R / V$ Endeavor from 26 June to 6 July 1997 (Figure 1), employed a towed, undulating sensor platform (SeaSoar) to conduct three-dimensional surveys along the southern flank of Georges Bank. SeaSoar profiled from the sea surface to depths of up to $130 \mathrm{~m}$ at typical tow speeds of 8 knots. In the shallower waters over the bank, a bottom avoidance system allowed the vehicle to profile to within $10 \mathrm{~m}$ of the seabed. Along-track horizontal resolution depended on tow speed and profile depth, ranging from approximately $1 \mathrm{~km}$ (in deep water) to $0.3 \mathrm{~km}$ (for bottom depths of $70 \mathrm{~m}$ ). Typical separations between tracks of $10 \mathrm{~km}$ were chosen to maximize survey coverage while resolving small-scale variability. The individual three-dimensional survey patterns each typically required $24-34 \mathrm{~h}$ to complete.

[7] SeaSoar carried a payload that included a Sea Bird $911+$ CTD system equipped with dual pumped conductivity and temperature sensors, a WET Labs chlorophyll fluorometer and transmissometer $(660 \mathrm{~nm}, 25 \mathrm{~cm}$ path length), a Biospherical Instruments photosynthetically available radiation (PAR) sensor, and a novel bioluminescence sensor [Fucile, 2002]. Quality control and processing followed Lee et al. [2000], with the resulting 1-s data binned in time $(6 \mathrm{~min})$ and depth $(2 \mathrm{~m})$ to produce distinct profiles. Because sampling did not include the direct pigment measurements needed to calibrate the chlorophyll fluorometer, its data are presented as simple sensor output voltages and referenced as "relative fluorescence."

\subsection{Velocity Data and Tides}

[8] A hull-mounted $150 \mathrm{kHz}$ narrowband Acoustic Doppler Current Profiler (ADCP) provided velocity measurements from 13 to $209 \mathrm{~m}$ depth. Ship velocities were estimated from GPS navigation data and, when within range, from ADCP bottom tracking. Data processing followed Firing et al. [1995] to produce absolute velocity profiles averaged over 4 min intervals and binned at $4 \mathrm{~m}$ in the vertical. Returns from the bottom $15 \%$ of the water column were excluded to avoid sidelobe contamination.

[9] Energetic tides, especially the semidiurnal $\left(\mathrm{M}_{2}\right)$ component [Brown and Moody, 1987], complicate isolation of the lower-frequency motions of interest to us here. To quantify the $\mathrm{M}_{2}$ tidal currents, we collapse cross-bank sections from the four summertime repeated intensive surveys (23 sections total) onto a common grid referenced by distance from the $300 \mathrm{~m}$ isobath. The resulting sections are binned $(\Delta y=10 \mathrm{~km}, \Delta z=10 \mathrm{~m})$ to produce irregularly spaced time series that provide dense sampling of the tidal phase space. Least squares fits of $\mathrm{M}_{2}$ period $(12.421 \mathrm{~h}$ ) sinusoids to each of these series provide estimates of tidal velocities as a function of depth and cross-bank distance. Accounting for the $\mathrm{K}_{1}(23.93 \mathrm{~h})$ tidal component does not improve the resulting fit. Frequent storm-induced gaps in the March surveys hamper attempts to make similar tidal estimates for the winter period. Only the summer surveys produce robust results.
[10] Tidal fits derived from summer surveys indicate that, in shallow waters over the bank, the semidiurnal tide can account for over $90 \%$ of the observed velocity variance. Tidal ellipses are oriented cross bank, with peak major (minor) axis amplitudes of $0.5(0.3) \mathrm{m} / \mathrm{s}$. Tidal velocities decrease with increasing bottom depth, and over the slope, the semidiurnal fit typically accounts for less than $25 \%$ of the observed variance. In shallow water, the ellipses exhibit little vertical structure beyond a slight decrease in magnitude in the bin closest to the seabed. In deeper waters over the slope, the fit exhibits low-mode vertical structure, but we question the significance of this result given the small fraction of the observed variance explained by the fit. Over the bank, these semidiurnal tidal estimates agree well in amplitude, phase, and (lack of) vertical structure with the barotropic model described by Flagg and Dunn [2003]. In deeper waters, where our results and the model disagree, significantly weaker tidal velocities make it difficult to isolate the semidiurnal signal. Given the excellent agreement between observed and modeled barotropic tides over the bank and the potential for improved estimates over the slope, we use the Flagg and Dunn [2003] model to estimate barotropic semidiurnal tidal velocities, which are then removed from the ADCP velocity records. Although we believe this approach to be optimal, it is not perfect. For example, predicted tidal amplitudes are typically about $0.25-0.4 \mathrm{~m} / \mathrm{s}$, while the lower-frequency signals of interest typically range between 0.1 and $0.3 \mathrm{~m} / \mathrm{s}$. Thus, even relatively small errors in the tidal estimate, such as $0.05 \mathrm{~m} / \mathrm{s}$ in amplitude or $10^{\circ}$ in phase, can produce errors that are a substantial fraction $(18 \%-80 \%)$ of the lower-frequency signal amplitude. Further, we account for neither the vertical structure of tidal currents nor for internal tidal variability. Given these large sources of uncertainty, we treat the detided velocities as being only qualitatively valid, and thus, we view higher-order calculations, such as direct estimates of property fluxes, with considerable skepticism.

[11] Spatial and temporal aliasing complicates the derivation of accurate spatial maps from measurements taken during surveys that last considerably longer than the advective time scale. Atop the bank, peak-to-peak semidiurnal barotropic tidal excursions as large as $7 \mathrm{~km}$, combined with displacements driven by low-frequency flows, could significantly distort mesoscale features captured in the 24 $34 \mathrm{~h}$ long individual surveys. We experimented with techniques that use estimates of tidal displacement to advect profile locations to a single moment in time. Our inability to resolve several troubling issues, including vertical profile distortion due to changing bottom depth and the effects of sheared velocity profiles, ultimately led us to abandon these calculations. Nonetheless, the attempt suggests some caveats for interpreting the data. Although sampling occurs rapidly enough to minimize tidal aliasing along individual sections, occupations of adjacent sections are typically separated by 5 or more hours. With tidal displacements that are similar in size to cross-track separations ( $7 \mathrm{~km}$ versus $12 \mathrm{~km}$ ), gradient calculations that rely on differences taken across two or more sections are unlikely to produce reliable quantitative results. This prevents us from estimating along-bank derivatives and so imposes significant restrictions on the analysis. 
Table 1. Representative Correlation Length Scales From the SeaSoar Data Set ${ }^{\mathrm{a}}$

\begin{tabular}{lccccc}
\hline & $\begin{array}{c}\text { Fractional } \\
\text { Error } \\
\text { Variance } \varepsilon\end{array}$ & $\begin{array}{c}a_{x} \\
(\mathrm{~km})\end{array}$ & $\begin{array}{c}b_{x} \\
\left(\mathrm{~km}^{-1}\right)\end{array}$ & $\begin{array}{c}a_{y} \\
(\mathrm{~km})\end{array}$ & $\begin{array}{c}b_{y} \\
\left(\mathrm{~km}^{-1}\right)\end{array}$ \\
\hline 10 m temperature & 0.04 & 13 & 100 & 14 & 100 \\
10 m density & 0.05 & 12 & 100 & 14 & 100 \\
10 m salinity & 0.02 & 12 & 100 & 12 & 100 \\
50 m temperature & 0.15 & 8 & 3 & 12 & 100 \\
56 m density & 0.15 & 8 & 100 & 13 & 100 \\
56 m salinity & 0.05 & 5 & 3 & 13 & 100 \\
& & & & & \\
10 m temperature & 0.03 & 15 & 100 & 15 & 100 \\
10 m density & 0.03 & 12 & 100 & 14 & 100 \\
10 m salinity & 0.01 & 16 & 100 & 13 & 100 \\
10 m temperature & 0.05 & 19 & 100 & 12 & 100 \\
56 m density & 0.05 & 15 & 100 & 12 & 100 \\
56 m salinity & 0.01 & 17 & 100 & 14 & 100 \\
\hline
\end{tabular}

${ }^{\mathrm{a}}$ The parameters $\varepsilon, a_{x}, b_{x}, a_{y}$, and $b_{y}$ are as defined in equation (2).

\subsection{Meteorological Measurements}

[12] Because both cruises yield only a limited suite of shipboard meteorological measurements, we use time series from a pair of nearby moorings to provide estimates of atmospheric forcing. Wind stress is calculated as described by Manning and Strout [2001] (following the parameterization of Large and Pond [1981]) from measurements taken at the Georges Bank South Flank NDBC mooring (Figure 1: Station $44011,41^{\circ} 05^{\prime} \mathrm{N}, 66^{\circ} 35^{\prime} \mathrm{W}$, data provided by $\mathrm{J}$. Manning). A mooring from the GLOBEC South Flank LongTerm Array $\left(40^{\circ} 58.0^{\prime} \mathrm{N}, 67^{\circ} 19.2^{\prime} \mathrm{W}\right.$ [Alessi et al., 2001]) provides surface heat flux estimates. In the absence of direct measurements, observed temperatures and estimated cloud cover are used to calculate long-wave radiation. Both mooring sites sample bank, as opposed to slope, conditions and are located within $150 \mathrm{~km}$ of the SeaSoar survey area. Sea surface temperature, which exerts a strong influence on surface fluxes, varies at scales smaller than $100 \mathrm{~km}$. Thus, although we use these flux estimates as a proxy for conditions over the entire survey region, some caution is warranted.

\subsection{Correlation Scales}

[13] Analysis of the SeaSoar survey measurements rests on an understanding of the dominant spatial and temporal scales. This is especially true in regions such as the southern flank of Georges Bank, where energetic short time-scale and space-scale variability dominates the observations. SeaSoar surveys do not provide sufficient temporal resolution to permit reliable estimation of the decorrelation time scales, although velocity measurements from the South Flank mooring [e.g., Brink et al., 2009] suggest e-folding times of 1-3 days for detided time series. Temporal scales for temperature and salinity appear to be longer.

[14] In order to quantify the dominant length scales for each sampling period, we estimate a structure function $S_{q q}$ as

$$
S_{q q}(\Delta \eta)=N^{-1} \Sigma(q(\eta)-q(\eta+\Delta \eta))^{2},
$$

where $\eta=x$ or $y$ (in a coordinate system rotated so that $x$ is along-isobath and $y=0$ is at about the $300 \mathrm{~m}$ isobath), and the sum is taken over all pairs of variable $q$ that are separated by $\Delta \eta$ while keeping time simultaneous to within $2 \mathrm{~h}$ and the other horizontal coordinate constant to within a $5^{\circ}$ arc around the baseline. Once the structure function is calculated, then it is straightforward to obtain the autocovariance function and fit it to the form

$$
R_{q q}=A_{q}(1-\varepsilon) \cos \left(b_{x} \Delta x+b_{y} \Delta y\right) \exp \left[-\left(\Delta x / a_{x}\right)^{2}-\left(\Delta y / a_{y}\right)^{2}\right],
$$

where the fractional error variance $\varepsilon$ is found by extrapolating the calculated correlation function to zero lag [Gawarkiewicz et al., 2004]. Values are then spot tested with objective fits to see if residuals of the fit are indeed white noise at the right amplitude. Our results suggest that the primary scale $a_{\eta}$ is estimated correctly to within about $2 \mathrm{~km}$ for hydrographic variables. In most cases, temperature, salinity, and density all have similar length scales in both seasons (Table 1). Further, the scales are nearly isotropic in most cases. In the cases where $a$ and $b$ are both small, it reflects the presence of a substantial sidelobe but not a correlation function that actually differs vastly relative to a case with large $b$ and $a$ around $12-15 \mathrm{~km}$. Although fronts are clearly anisotropic, the highly three-dimensional nature of mesoscale variability over the bank and slope (e.g., meanders, bends, and intrusions) prevents any one survey from having a single "preferred" orientation. This produces isotropic statistics when considering surveys as a whole.

\section{March 1997}

\subsection{Overview}

[15] The March 1997 sampling program focused on potential cross-frontal exchange driven by strong, episodic atmospheric forcing. Cruise operations compromised between the desire to sample around a major wintertime storm and our limited ability to operate in severe conditions. Satellite remote sensing confirms the absence of major offshore influences (such as Gulf Stream warm core rings) impinging on the southern flank of Georges Bank, though a cold tongue, tapering away toward the southwest, in the sea surface temperature (SST) imagery hints at the presence of a Scotian Shelf crossover event (Figure 2). Previous investigations [Bisagni et al. 1996; Smith et al. 2003] documented similar crossover events and hypothesized that they may drive a significant freshwater flux onto the bank. Several factors, including the extent of on-bank penetration and the timing and strength of mixing, are expected to govern the net crossover-driven freshwater flux.

[16] The March cruise began with a simple survey immediately before the onset of a major winter storm (Figure 3). During the storm, hourly averaged eastward wind stress peaks at over $1 \mathrm{~N} \mathrm{~m}^{-2}$, producing heavy seas and forcing the ship to stop sampling. Although dangerous operating conditions prevented sampling during the event, a second occupation of the survey (in three fragments) after the storm's passage facilitates evaluation of its integrated effect.

\subsection{Water Mass Changes}

[17] An intrusion of anomalously cold $\left(2-4^{\circ} \mathrm{C}\right)$, fresh $(S<$ 32 ) water occupies the upper $20-50 \mathrm{~m}$ of shelf break region 


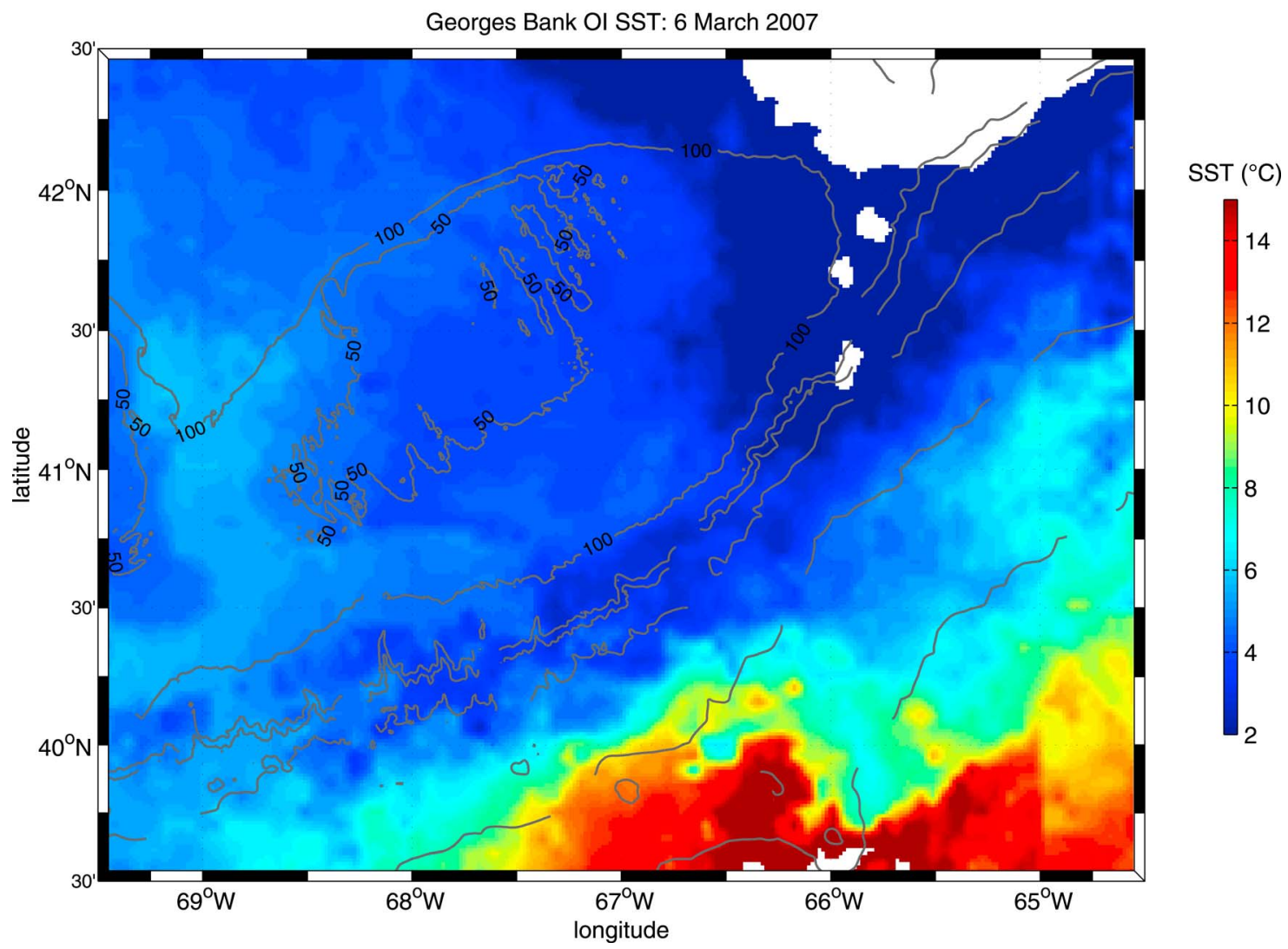

Figure 2. Optimally interpolated AVHRR sea surface temperature map for 6 March 1997. A cool intrusion extends from the Scotian Shelf across to the Georges Bank southern flank. Gray lines mark selected isobaths.
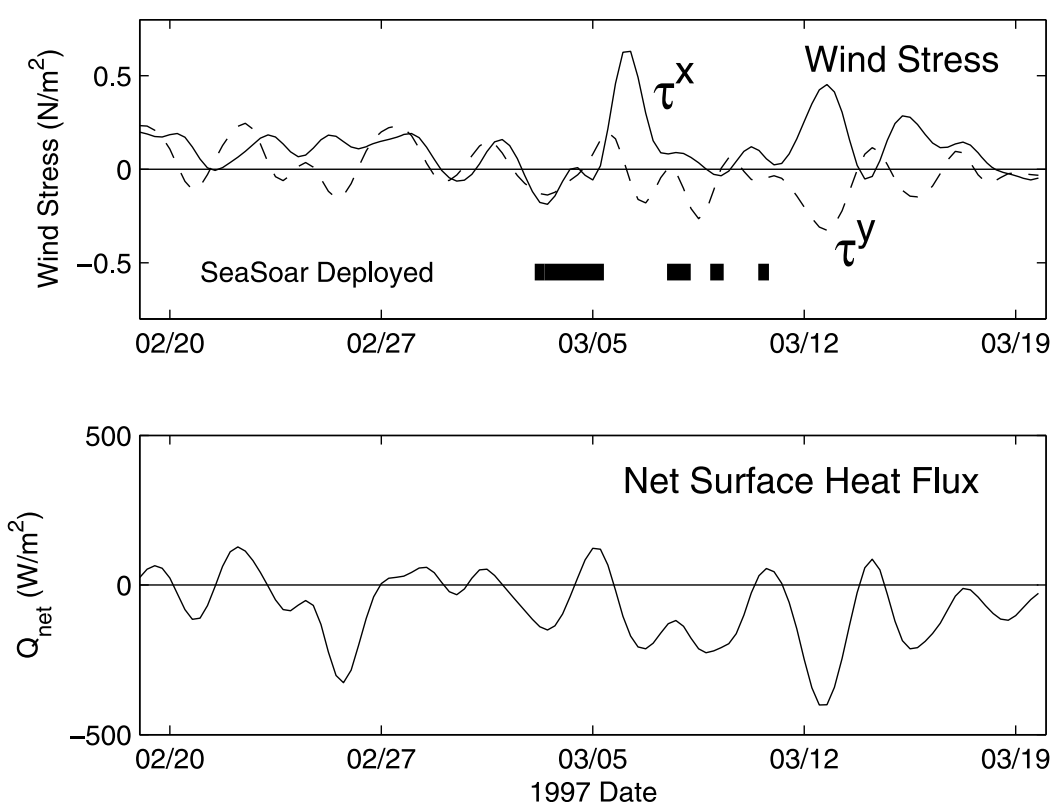

Figure 3. (top) Low-pass filtered (48 h) eastward (dashed) and northward (solid) wind stress during the March 1997 GLOBEC2 cruise period at NDBC buoy 44011. (bottom) Low-pass filtered (48 h) net surface heat flux, plotted such that positive heat flux indicates ocean warming. Wide, solid lines denote SeaSoar sampling times. 


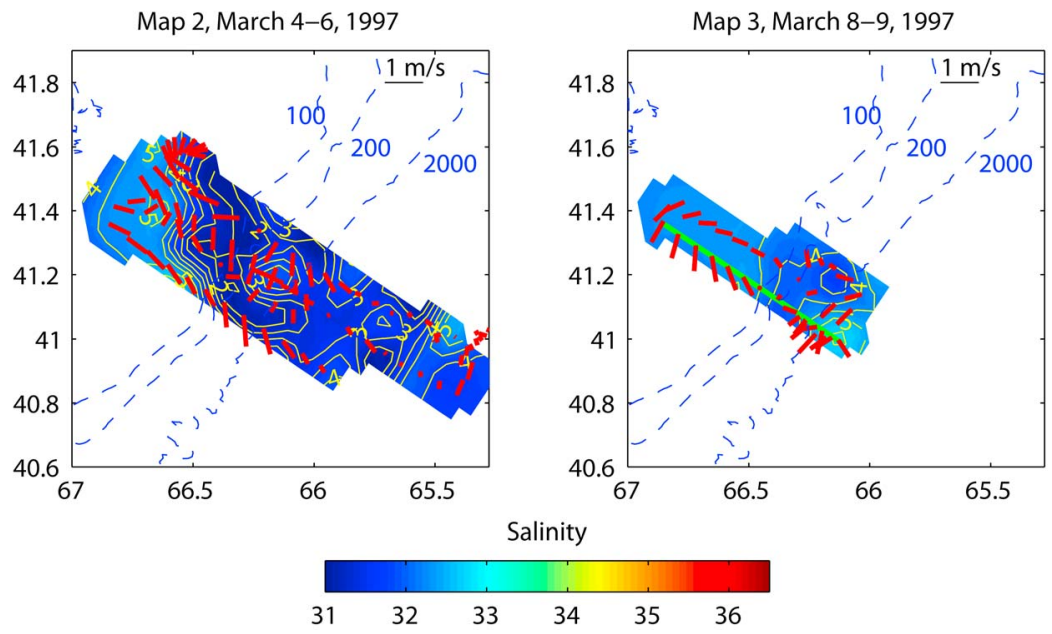

Figure 4. Objective maps of $10 \mathrm{~m}$ salinity (color) and potential temperature (yellow contours) made from surveys occupied immediately before (4-6 March, left) and after (8-9 March, right) the major storm event. Red vectors depict detided ADCP currents at $18 \mathrm{~m}$ depth, with velocity scales indicated in the upper right corner of each panel. Dashed blue contours mark the 100, 200, and $2000 \mathrm{~m}$ isobaths. The solid green line at the right shows the location of the section shown in Figures 5, 7, and 9.

during the initial (prestorm) survey (Figures 4, left and 5). Both water properties (Figure 5) and satellite remote sensing (Figure 2) suggest that the observed feature is an extension of Scotian Shelf water, reaching from Brown's Bank across the Northeast Channel. Scotian Shelf waters extend across the entire easternmost section, reaching over $30 \mathrm{~km}$ on-bank of the $100 \mathrm{~m}$ isobath (Figure 4, left). On-bank penetration decreases westward, with the intrusion reaching less than $10 \mathrm{~km}$ beyond the $100 \mathrm{~m}$ isobath in the westernmost section. In all four sections, Scotian Shelf water extends on-bank well past the foot of the shelf break front.

[18] The Scotian Shelf crossover produces dramatic structural changes in the wintertime shelf break front. Off- bank of the shelf break, temperature and salinity both increase with depth, delineating transitions between Scotian Shelf (freshest, $S<32$ ), bank (fresh, $32<S<33.6$ ), and slope $(S>33.6$, which includes the shelf slope front and slope regimes defined by Lentz et al. 2003) waters (Figure 5). $T-S$ properties from the bank's northern flank and crest (Figure 6, compare prestorm $\mathrm{CR}$ and NF with SF signature) indicate that along-bank advection of low-salinity waters entrained from the Gulf of Maine cannot account for the observed freshening along the southern flank because prestorm upstream waters (Figure 6, NF and CR, pink and blue triangles) are not fresh enough to account for low poststorm salinities (blue dots) over the southern flank. The salinity-
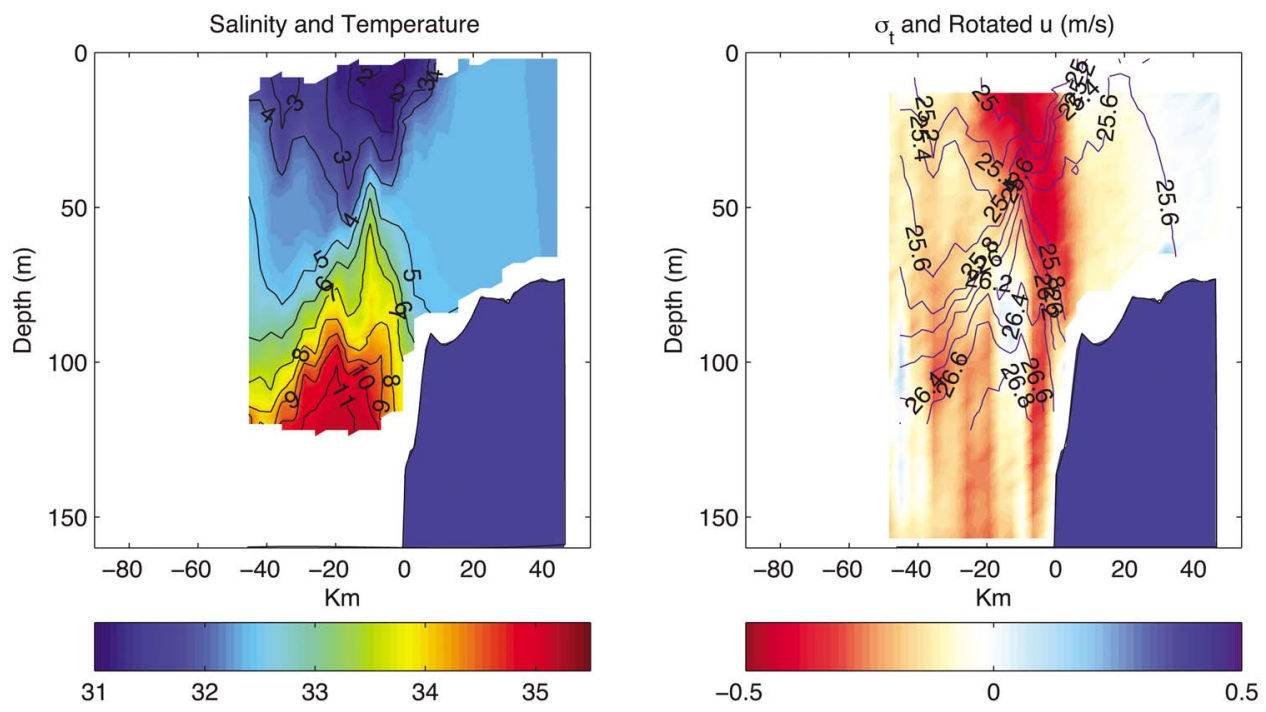

Figure 5. Cross-isobath section taken immediately before the major storm event (6 March 1997). (left) Salinity (color) and temperature (contours) and (right) along-isobath ADCP currents (m/s, rotated $56^{\circ}$, color), positive toward the northeast, and potential density (contours). The green line in Figure 4 (right) marks section location. 


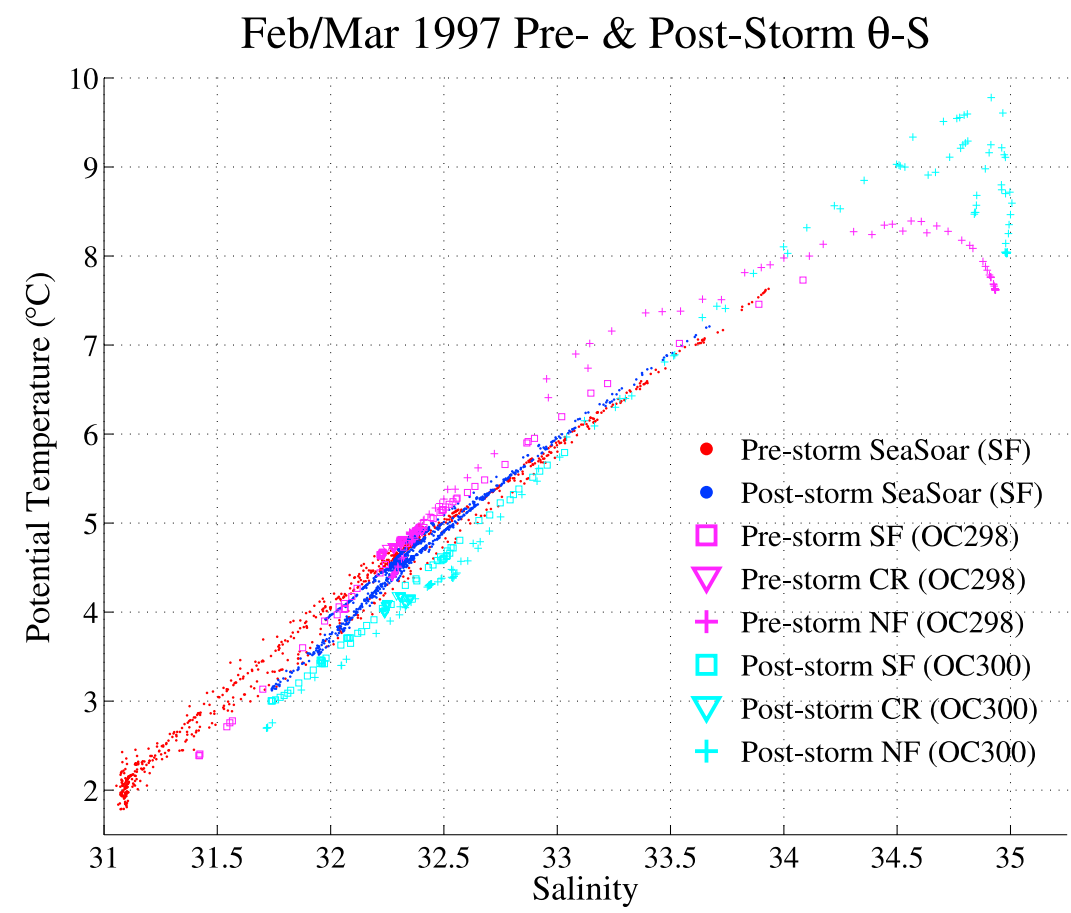

Figure 6. Watermass properties for prestorm (red dots) and poststorm (blue dots) SeaSoar surveys contrasted against measurements collected over the northern flank (NF), bank crest (CR), and southern flank (SF) during prestorm (pink, OC298) and poststorm (light blue, OC300) broadscale cruises. Although bank crest data are plotted, the points are largely obscured by other, more heavily sampled water mass classes. Refer to Figure 1 for profile locations.

dominated density profile off-bank is consistent with expected wintertime stratification but enhanced by the additional freshwater cap. Farther on-bank, strong temperature, salinity, and potential density gradients intersect the bottom near the $100 \mathrm{~m}$ isobath and define the shelf break front. In contrast to the relatively gentle off-bank slope and eventual outcrop of frontal isopycnals expected from previous observations [e.g., Linder and Gawarkiewicz, 1998], the layer of Scotian Shelf water evidently shifts the outcropping farther offshore. Thus, none of the sections extend far enough off-bank to capture the front's surface expression. Instead, the shelf break front (as often represented by the $26 \mathrm{~kg} \mathrm{~m}^{-3}$ isopycnal) rises gradually to a depth of no less than $50 \mathrm{~m}$ well south of the $100 \mathrm{~m}$ isobath, staying below the influence of the Scotian Shelf crossover, which is confined to the upper $20-50 \mathrm{~m}$.

[19] Following the storm, the lowest temperatures at $10 \mathrm{~m}$ depth (near the shelf break) have disappeared, although a slight cooling is evident inshore of around the $100 \mathrm{~m}$ isobath (Figure 4, right). Along the southern flank, waters fresher than 31.8 have vanished, but salinities near the shelf break remain low enough to confirm the impact of the Scotian Shelf crossover on shelf slope freshwater content, as neither the northern flank nor crest could have contributed waters fresh enough to produce observed poststorm southern flank salinities (Figure 6). A broadscale hydrographic survey (Figure 6, OS300; see Townsend and Thomas [2001] for a description of this sampling) conducted in the weeks following SeaSoar sampling detects no freshening over the crest, but some freshening over the northern flank (perhaps due to impinging Scotian Shelf waters). Southern flank conditions remain consistent with those observed during the poststorm SeaSoar surveys.

[20] The observed along-bank advection speeds that exceed $1 \mathrm{~m} / \mathrm{s}(86 \mathrm{~km} / \mathrm{d})$ and the 2 or more day gap between surveys prevent the tracking of specific water mass features between SeaSoar occupations. We can nonetheless constrain the possibilities for several reasons. Poststorm cross-frontal sections (Figure 7, along the same section as in Figure 5) and $T-S$ properties (Figure 6, light blue symbols) suggest that Scotian Shelf crossover waters remain over the southern flank. Overall water mass structure remains qualitatively similar to that observed in the prestorm section, with a front rising off-bank from the shelf break and sinking again near $y=-20 \mathrm{~km}$. The freshest, coldest waters associated with the prestorm Scotian Shelf crossover have been replaced by a slightly more saline, warmer water mass whose properties are consistent with a mixture of crossover waters and the ambient (deeper or off-bank) warmer, saltier waters.

\subsection{Surface Versus Lateral Fluxes}

[21] Changes in vertically integrated heat and salt content (between the surface and the $\sigma_{t}=26.0 \mathrm{~kg} \mathrm{~m}^{-3}$ surface or the bottom in the absence of the $\sigma_{t}=26.0 \mathrm{~kg} \mathrm{~m}^{-3}$ surface) help constrain the relative roles of surface fluxes and advection. The $\sigma_{t}=26.0 \mathrm{~kg} \mathrm{~m}^{-3}$ surface is chosen because (1) there is always water less dense than this in all sections and (2) when present, this isopycnal is always embedded in the pycnocline, so that we believe it to be below the maximum depth to which mixing occurred. For each of the four repeated SeaSoar survey lines, we compute the prestorm to poststorm difference in the vertically integrated heat and salt 

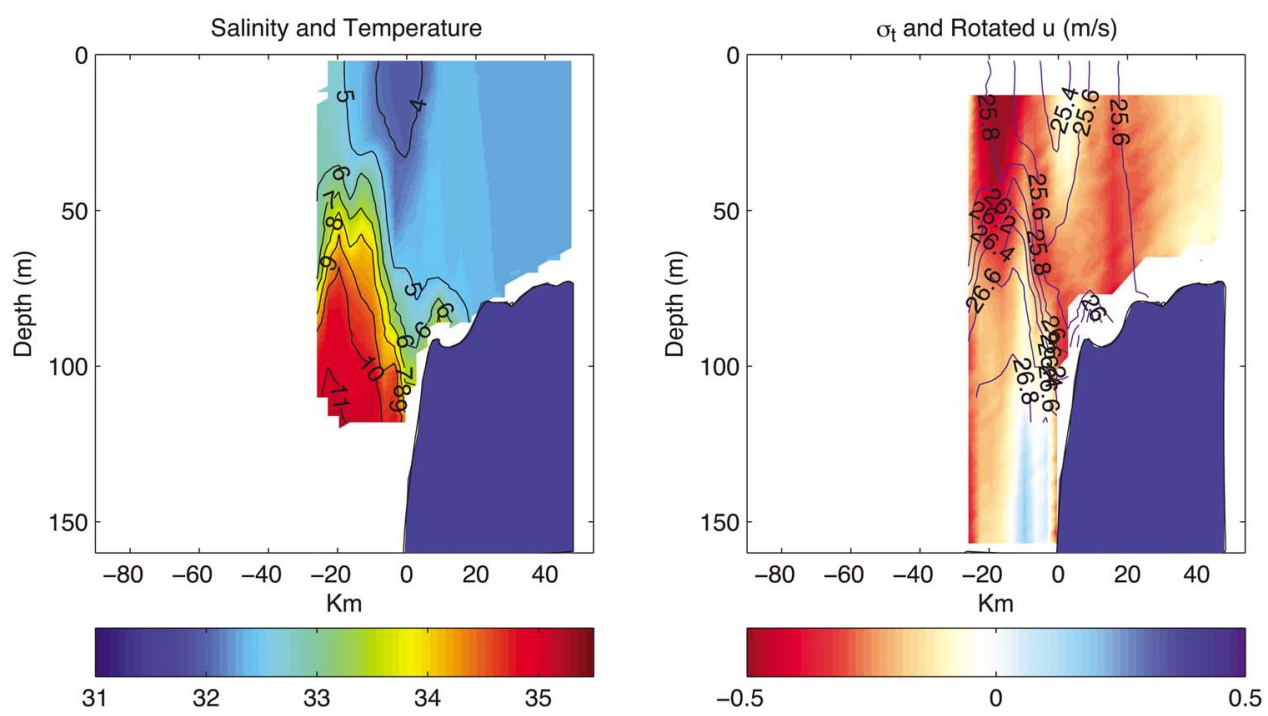

Figure 7. Cross-isobath section taken immediately after the major storm event (9 March 1997). (left) Salinity (color) and temperature (contours) and (right) along-isobath currents $\left(\mathrm{m} / \mathrm{s}\right.$, rotated $56^{\circ}$, color), positive toward the northeast, and potential density (contours). The green line in Figure 4 (right) marks section location.

contents. Dividing by the time interval between occupations provides an estimate of average rates of change.

[22] The results for salt content (Figure 8b) are used to evaluate the importance of advection, since (in the absence of strong evaporation or precipitation) salt should be con- served unless lateral advection is important. For $y>30 \mathrm{~km}$, well inshore of the shelf break front (typically found at the bottom near $y=0 \mathrm{~km}$ ), there is no substantial change in the integrated salt content, so we conclude that advective effects are not very important over that part of the bank at this time.
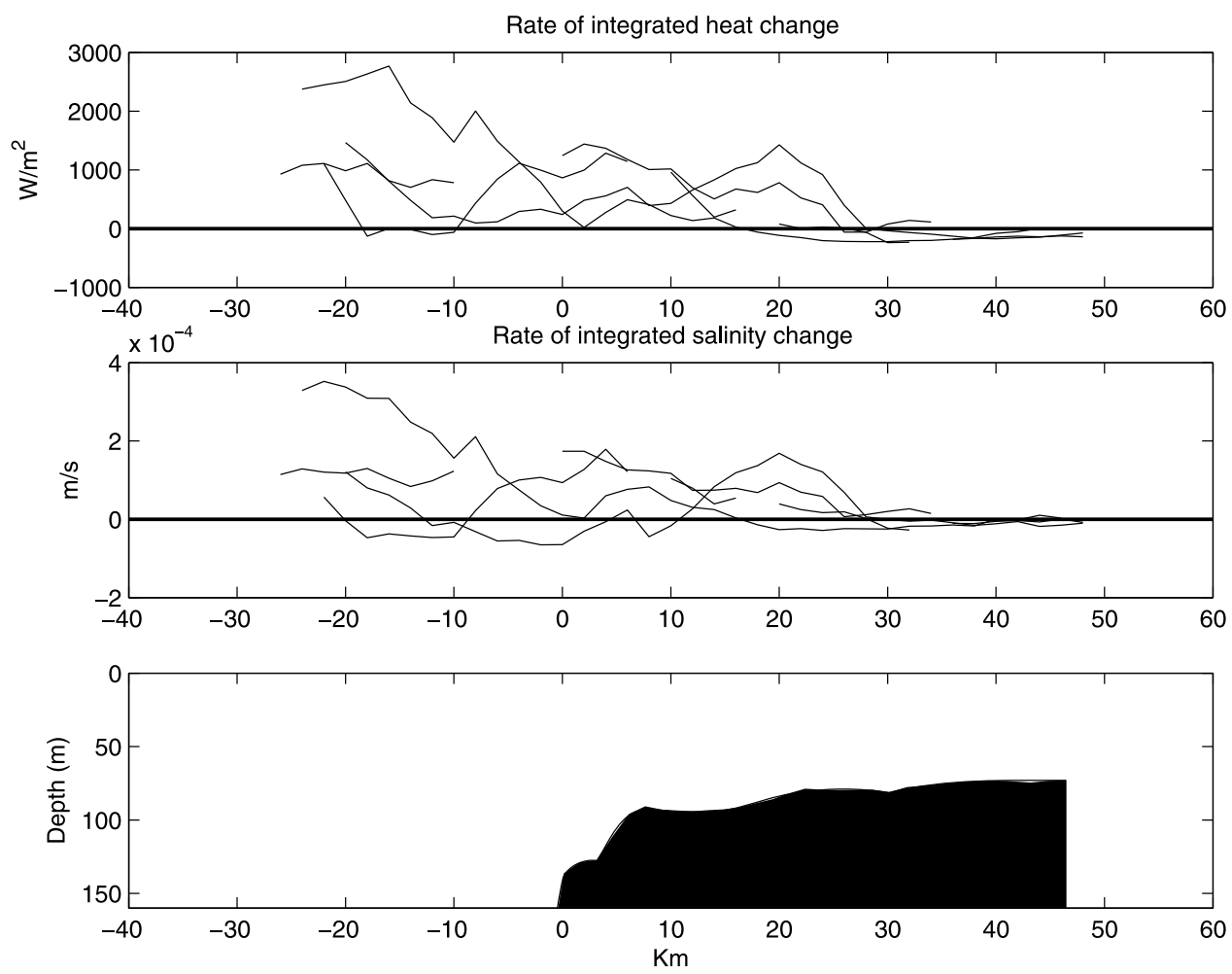

Figure 8. Rate of change in depth integrated (from the surface to the $26 \mathrm{~kg} \mathrm{~m}^{-3}$ isopycnal or to the bottom, whichever is shallower) heat and salt content, comparing identical sections immediately before and after the GLOBEC2 storm passage. Different lines are computed from different cross-shelf sections, with a representative bathymetric profile plotted in the bottom. 


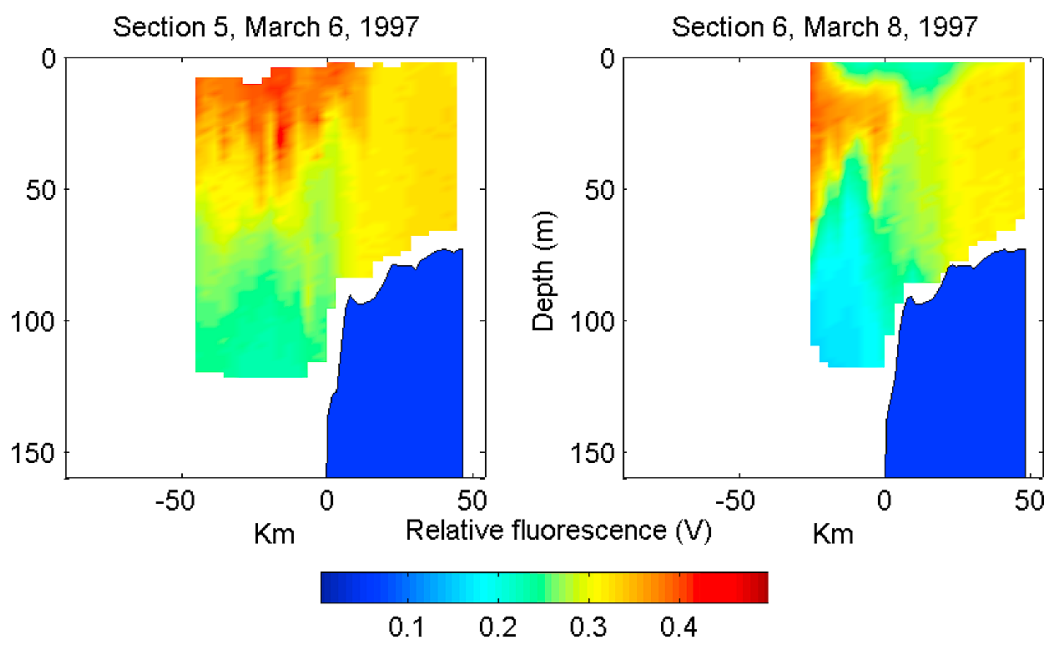

Figure 9. Relative fluorescence (sensor volts) immediately (left) before and (right) after the March, 1997 storm event. The green line in Figure 4 (right) marks section location.

Off-bank of $y=30$ (in deep water and over the outer bank), salt is wildly nonconservative and in a way that is not even consistent from one line to the next. We might expect advective processes to be particularly important, as the shelf break front is carried back and forth by the tides with excursions of about $7 \mathrm{~km}$, but since large changes in salt content occur over a broader cross-bank range than $7 \mathrm{~km}$, we expect that other strong flows associated with the front also play important roles. Changes in integrated salt content thus demonstrate that advective processes are important in the outer bank and deeper waters.

[23] Integrated heat content changes (Figure 8a) reveal cooling of roughly $100 \mathrm{~W} \mathrm{~m}^{-2}$ well over the bank $(y>30 \mathrm{~km})$ and much stronger changes near the bank edge and beyond. The magnitude and relatively uniform spatial structure of integrated heat content changes for $y>30 \mathrm{~km}$ suggest that surface cooling may be the primary driver there. Dailyaveraged direct heat flux estimates at the GLOBEC south flank mooring yield an average cooling of approximately $100 \mathrm{~W} \mathrm{~m}^{-2}$ (Figure 3) over this interval, with instantaneous values showing a flux into the ocean during the storm's earlier phases and outgoing toward the end. In outer bank and slope waters $(y<30 \mathrm{~km})$, heat changes are too large (typically exceeding $1000 \mathrm{~W} / \mathrm{m}^{2}$ ) and spatially variable to be accounted for by surface forcing alone, suggesting again that advection must play an important role.

[24] Changes in integrated heat and salt content indicate that one-dimensional vertical mixing processes dominate well over the bank (typically inshore of the $80 \mathrm{~m}$ isobath or about $30 \mathrm{~km}$ onshore of the shelf break) but that advective or lateral mixing processes dominate in deeper water, including at the bank edge. This conclusion is consistent with that of Lentz et al. [2003], who use moored array data to demonstrate that water mass changes near the $75 \mathrm{~m}$ isobath over the bank proper are indeed one-dimensional during the wintertime.

\subsection{Frontal Position}

[25] We had expected a priori that, in response to the eastward wind stress, the shelf break front would be distended toward deeper water, at least in the upper tens of meters [Ou, 1984; Fong and Geyer, 2001]. Our measurements show no sign of this type of response, although this finding is hardly conclusive because the frontal surface intersection was never observed. One very modest hint, however, occurs in the relative fluorescence sections (Figure 9), where the maximum values move off-bank by at least $10 \mathrm{~km}$ during the storm. This upper ocean displacement is roughly what one would expect for Ekman transport in a $50 \mathrm{~m}$ mixed layer, but we can certainly not discount the possibility of alongshore advection.

[26] In contrast, the frontal intersection with the bottom, as defined by the $26 \sigma_{t}$ surface, is remarkably fixed. The intersection isobath is estimated by extrapolating through the unsampled bottom $10 \mathrm{~m}$ of the water column. Of the four prestorm cross-shelf sections, the mean intersection falls at the $99 \mathrm{~m}$ (standard deviation, $3 \mathrm{~m}$ ) isobath. After the storm, the intersection also falls at the $99 \mathrm{~m}$ isobath, with a standard deviation of $3 \mathrm{~m}$ for six sections. The consistency of this intersection is predicted by Chapman [2000], who shows that, because of buoyancy arrest in the bottom boundary layer, the shelf break frontal jet ought to adjust so that the current and the bottom front follow isobaths exactly. Chapman's model does not account for wind forcing or tides, so our present, single comparison suggests that these added effects may not be important for setting the frontal bottom location. While Ou's [1984] model of frontal geostrophic adjustment in response to winds does show the front's bottom intersection moving in response to the wind, his model does not include the boundary layer physics or continuous stratification that are so crucial to Chapman's model. Our tentative conclusion is that, in the upper ocean, the front does move offshore as expected, but that it is unmoved at the bottom. How the offshore mass flux is balanced remains a question.

\subsection{Geostrophy}

[27] An evaluation of the thermal wind equation indicates that geostrophy fails to describe the dominant instantaneous across-bank momentum balance. We compute the thermal wind velocity relative to $70 \mathrm{~m}$ depth for all 10 sections taken in the area covered by Figure 4 . These velocity estimates are 

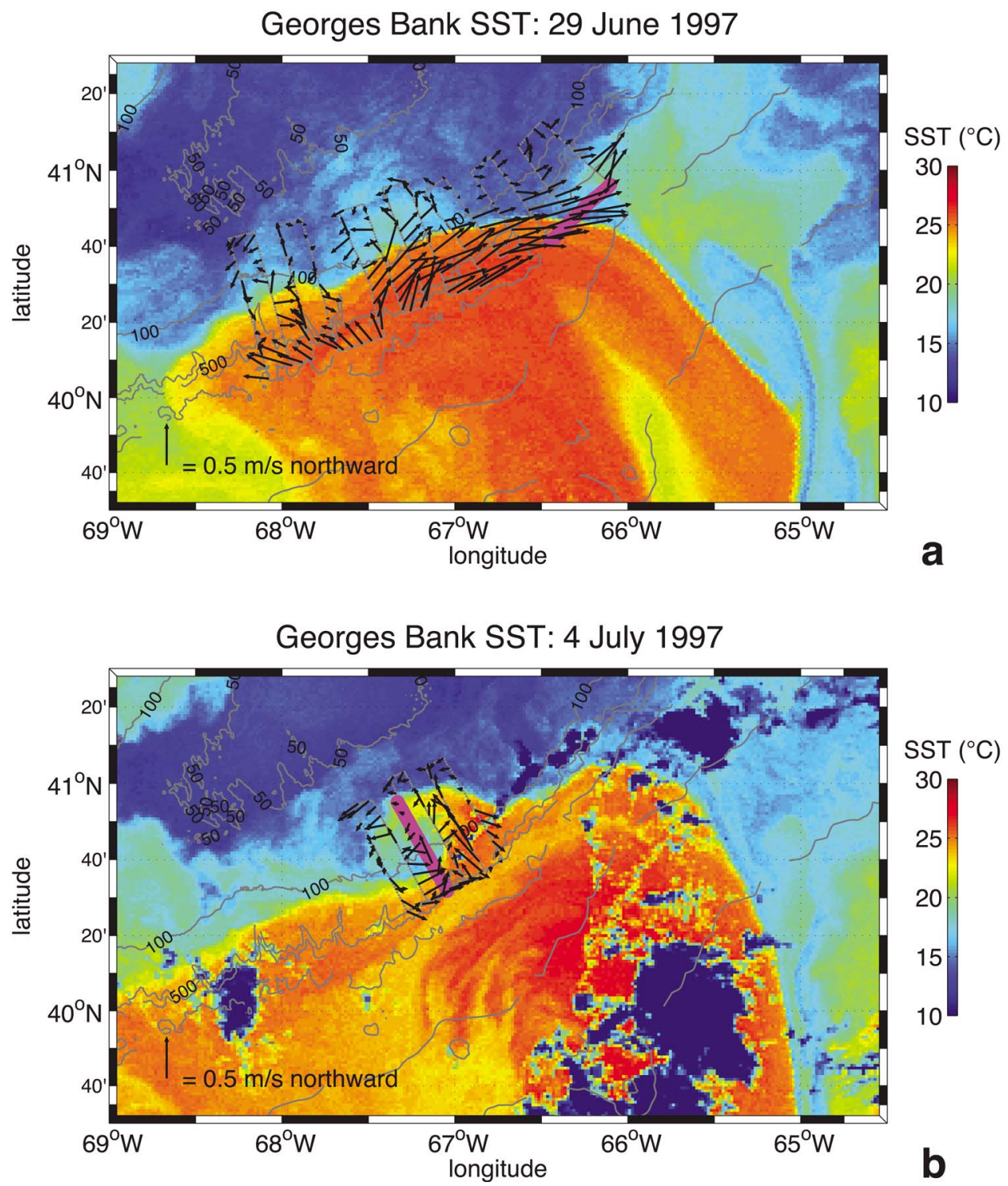

Figure 10. (a) 29 June 1997 AVHRR image and south flank survey ADCP velocity vectors (22 m) with a magenta line marking the cross-extrusion section plotted in Figure 10. (b) 4 July 1997 AVHRR image and intrusion survey velocity vectors with a magenta line marking the section plotted in Figure 12.

then compared to velocities (relative to $70 \mathrm{~m}$ ) obtained directly from the detided shipboard ADCP. When all 10 sections are first averaged together in $10 \mathrm{~km}$ cross-bank bins and then the mean velocities are computed, agreement is poor, with a regression coefficient of $0.18 \pm 0.73$ ( \pm 1 standard error) between measured velocity and thermal wind. The regression worsens when the data are spatially smoothed by doubling the bin size. When individual sections are considered, the regression coefficients ranged between -0.4 and 0.6 . In all cases, the regression coefficient is within $95 \%$ confidence of both zero and unity, and it is always within $67 \%$ confidence of zero.

[28] These results indicate that, under strongly forced wintertime conditions, thermal wind and, hence, geostrophy fail to account for observed shear variance in the upper $120 \mathrm{~m}$ near the shelf break. Some combination of a significant, directly wind-driven response, energetic near-inertial mo- tions, internal tide, and other ageostrophic sources of shear likely dominate the record, swamping the geostrophic contribution. In a similar domain (the summertime shelf edge $400 \mathrm{~km}$ west of Georges Bank), Gawarkiewicz et al. [2004] found that variability at diurnal and higher frequencies dominated instantaneous ADCP shears. The thermal wind relation is not expected to hold for such rapidly varying flows. Further, Gawarkiewicz et al. [2004] found that there were substantial nonlinearities (Rossby numbers of order $0.3-0.5$ ) that made a pure geostrophic balance unlikely even if the flow was steady. By comparison, our ADCP measurements (Figure 4) show peak speeds at $18 \mathrm{~m}$ of about $1 \mathrm{~m} / \mathrm{s}$ and spatial variations that are consistent with an $O(0.5)$ Rossby number. (Some of the strongest lateral shears are found off the bank, where tides are weak, so it is unlikely that the observed horizontal shears are residuals of imperfect tidal removal.) Since there are no moorings within 


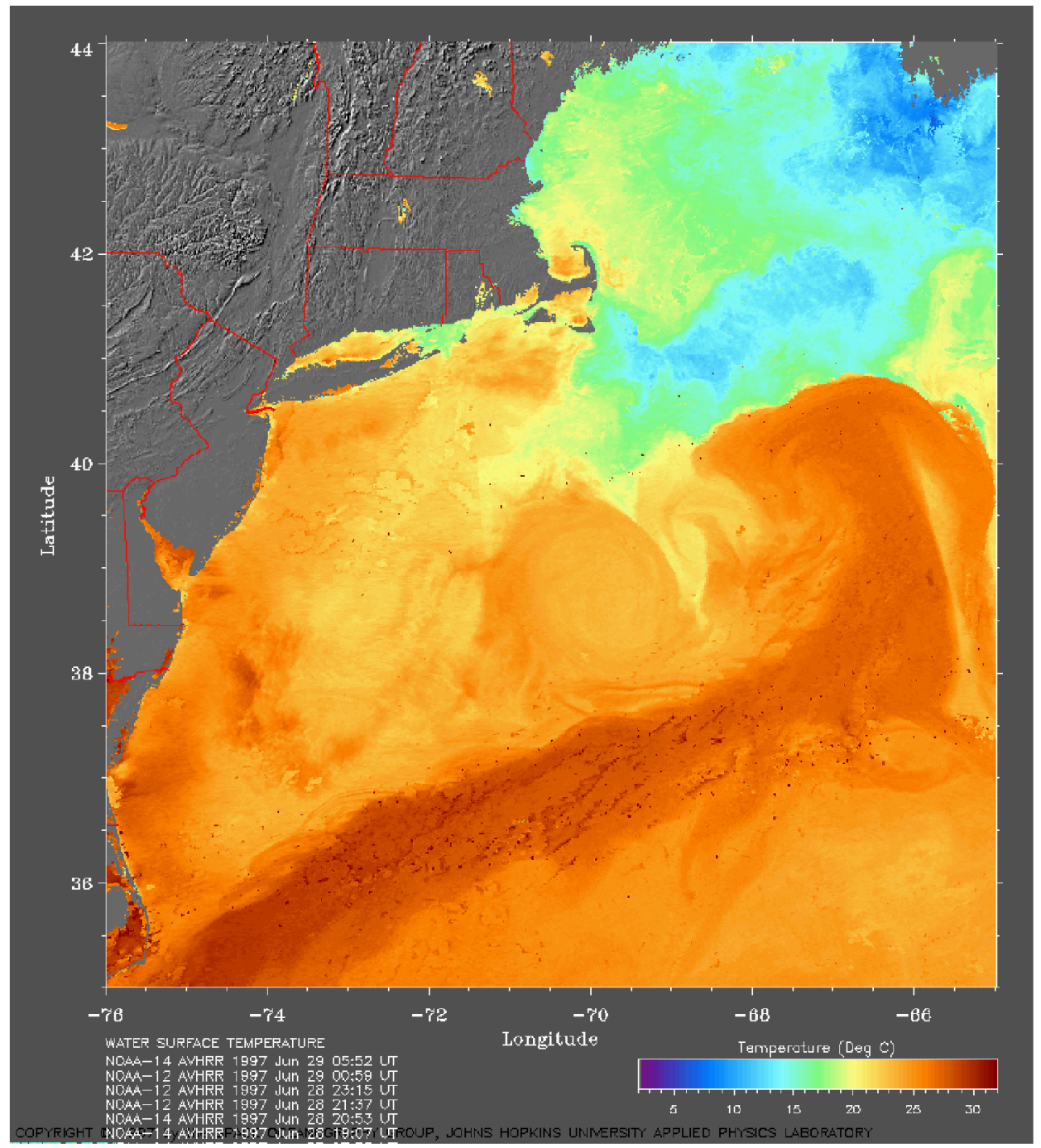

Figure 11. Composite AVHRR sea surface temperature image for 29 June 1997. A Gulf Stream meander impinges on Georges Bank at approximately $67^{\circ} \mathrm{W}$. Image courtesy of the Space Oceanography Group, Applied Physics Laboratory, Johns Hopkins University.

our immediate survey area, we cannot directly assess highfrequency variability, but we also have no reason to expect that it is less important here than to the west. Under these circumstances, we should not be surprised that the thermal wind does not compare well with observed instantaneous shears.

\section{June-July 1997}

\subsection{Overview}

[29] Summertime observations begin with an exploratory survey that extends across much of the southern flank (Figure 10a), designed to characterize the bank edge front and the impact of a nearby Gulf Stream meander that dominates the remotely sensed SST (Figure 11). The first eight cross-shelf sections (western and central southern flank) reveal strong stratification in the upper $50 \mathrm{~m}$ and weak alongshore variability in the bank edge front. For example, on the western side, the surface front generally parallels the $100 \mathrm{~m}$ isobath, but weak meanders having wavelengths of
25-40 km are found overall. The easternmost portion of this survey differs dramatically, with the front extending offshore (south) following a 10-20 km wide cool extrusion of bank water. Winds remain weak through the measurement period, never exceeding $8 \mathrm{~m} / \mathrm{s}\left(0.06 \mathrm{~N} \mathrm{~m}^{-2}\right)$, with $3 \mathrm{~m} / \mathrm{s}\left(0.02 \mathrm{~N} \mathrm{~m}^{-2}\right)$ more typical.

[30] Large-scale SST images (Figure 11) and survey results (Figure 10) document the evolution of the impinging Gulf Stream meander and associated intrusion and extrusion events that dominate variability over the bank during the summertime measurement program. The coolest surface waters occupy central Georges Bank and the region near Nova Scotia, while the warmest oceanic waters are generally associated with the Gulf Stream. After departing Cape Hatteras $\left(35^{\circ} 30^{\prime} \mathrm{N}\right)$, the Gulf Stream flows east northeast to roughly $68^{\circ} \mathrm{W}, 37^{\circ} 30^{\prime} \mathrm{N}$, where it appears to turn abruptly northward. Although sea surface temperature provides an incomplete picture, it appears that a sharp northward meander impinges on the southern edge of Georges Bank near $40^{\circ}$ $30^{\prime} \mathrm{N}$. Detided upper ocean velocities (22 m; Figure 10a) 

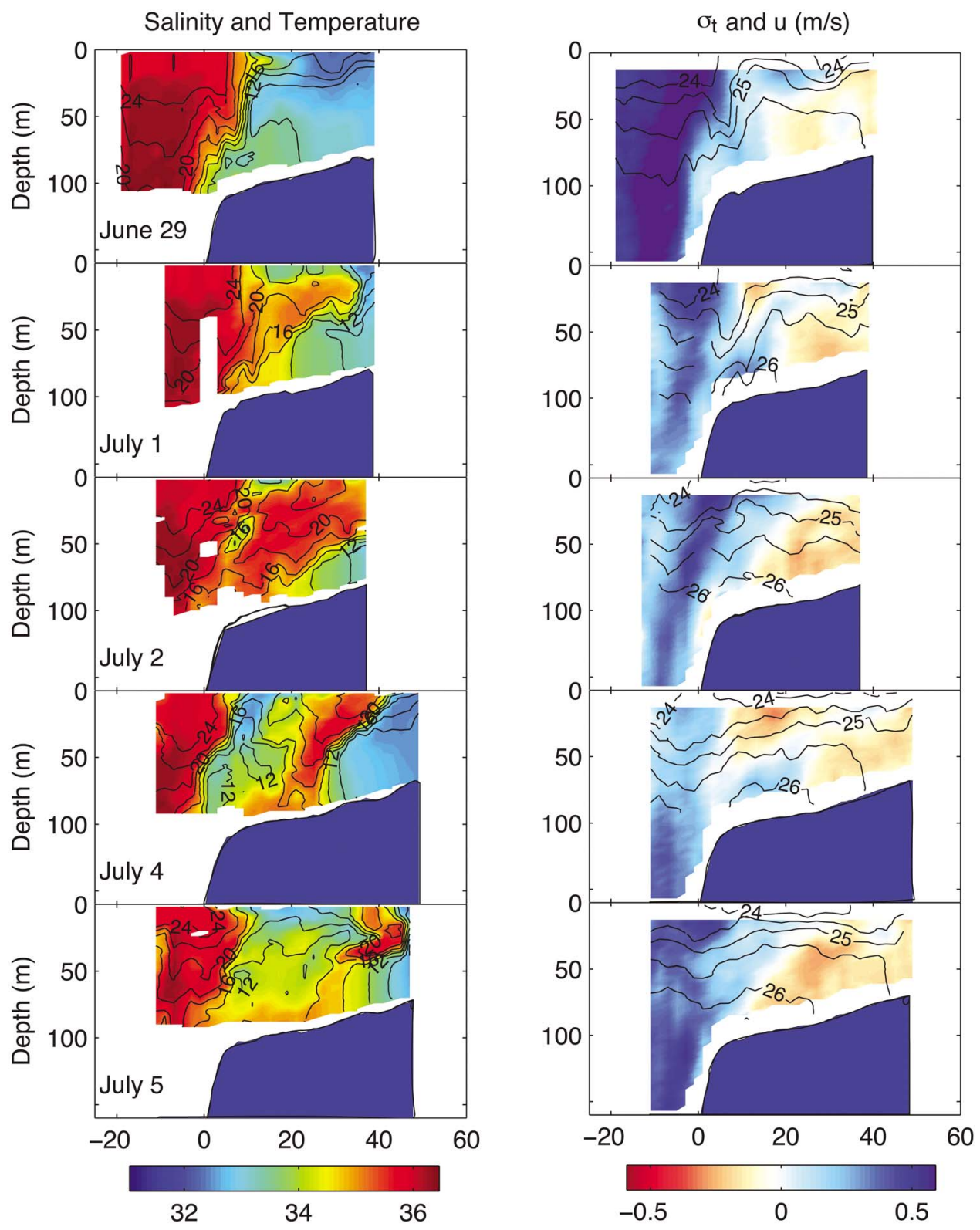

Figure 12. Time series of cross-isobath sections along the central sampling line (magenta line in Figure 10b and the last panel of Figure 14) during the GLOBEC3 (summer) sampling period. (left) Salinity (color) and temperature (contours) and (right) along-isobath currents (m/s, rotated $28^{\circ}$, color), positive toward the northeast, and potential density (contours).

reveal northward meander currents bifurcating as they encounter the bank, with velocities in the eastern (western) side flowing east (west). Downstream, the eastward branch appears to split again with one limb following the isobaths, as they turn to the northeast and the other continuing eastward, tracing the meander edge. This eastward branch coincides with the cold extrusion captured in the 29 June SST image (Figure 10a), apparently marking the entrainment and off-bank transport of bank water by the strong flows associated with the Gulf Stream meander.

[31] An SST image taken 6 days later reveals that this anomalous northward meander remains in place, with the addition of a small, westward-tilting tongue of warm water at its end (Figure 10b) that extends slightly farther north into waters shallower than $100 \mathrm{~m}$. Ten days later (not shown), the large northward Gulf Stream meander evolves into a distinct warm core ring, centered near $66^{\circ} 30^{\prime} \mathrm{W}, 39^{\circ} 45^{\prime} \mathrm{N}$, that is clearly separated from the core Gulf Stream (which returns to south of about $38^{\circ} 30^{\prime} \mathrm{N}$ ). Upper ocean intrusions of warm core ring water onto the bank (Figure 10b) appear to be unusual, although Flagg [1987] uses a less comprehensive data set to document a similar example during a 1977 event. Mountain et al. [1989] report evidence of episodic autumnal intrusions farther west, in the trough of the Great South Channel, but these appear to differ from Flagg's or the present case because the channel intrusions are bottom-intensified. 

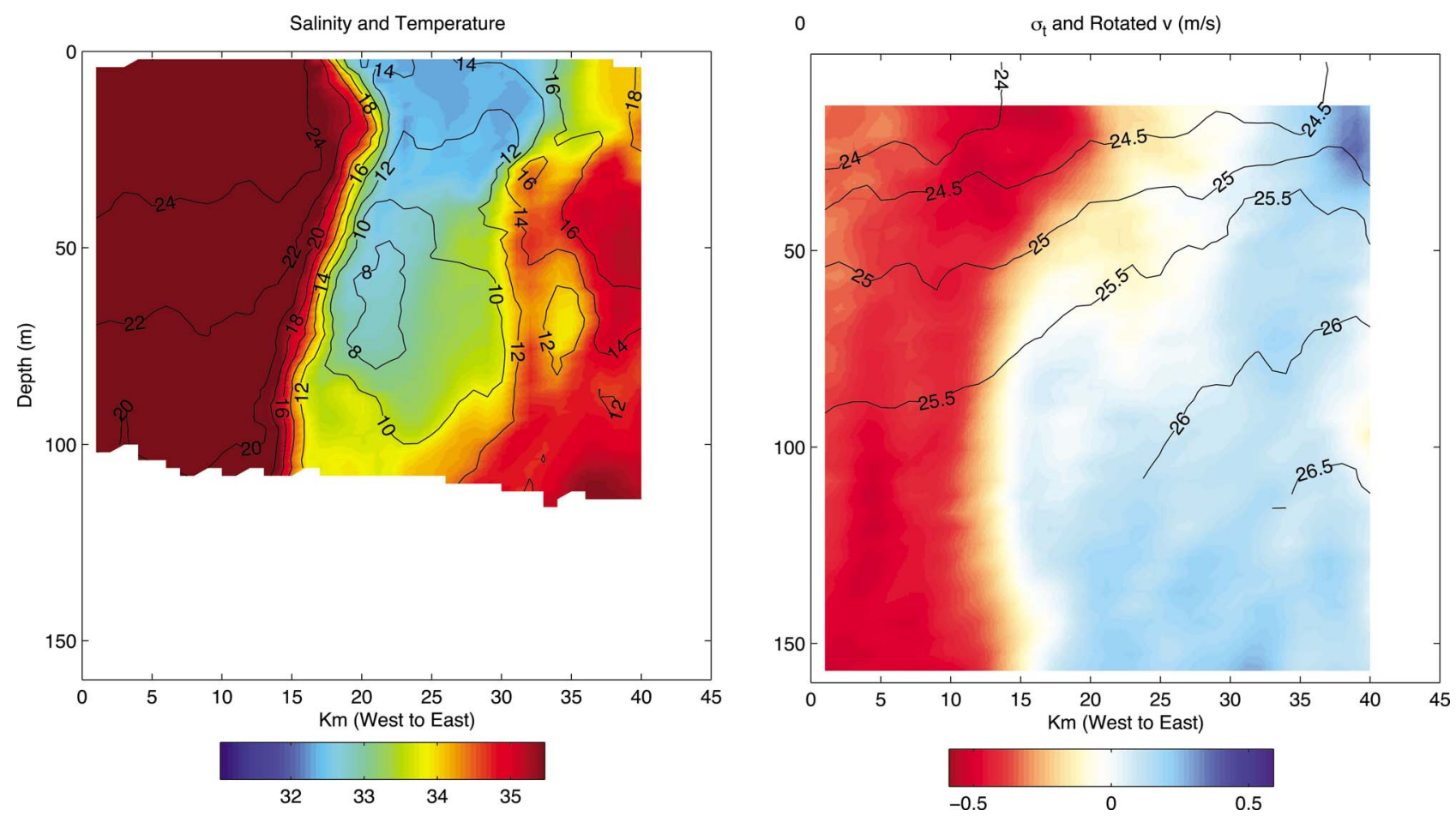

Figure 13. Cross-streamer sections of (left) temperature (contours) and salinity (color) and (right) density (contours) and normal velocity (color, m/s) occupied on 29 June 1997 on a line running roughly orthogonal to the front between the warm-core ring and the bank water being drawn offshore (Figures 1 and 10a, magenta line). Negative velocities indicate off-bank flow.

[32] Following the broad, exploratory survey (Figure 10a), measurement efforts focused on evolution of the front formed between bank and Gulf Stream waters near $67^{\circ} \mathrm{W}, 40^{\circ} 36^{\prime} \mathrm{N}$. A series of three-dimensional surveys (e.g., Figure 10b) document evolution of the small, tongue-like intrusion, as it grows and extends past the $100 \mathrm{~m}$ isobath toward the bank crest.

\subsection{Initial Shelf Break Structure}

[33] West of the cool extrusion, the shelf break front evolves rapidly in response to the energetic impinging flow. On 29 June, when the front is relatively straight, cross-front sections (e.g., Figure 12, top) reveal a bank edge front that tilts toward shallow water as it approaches the surface. This tilt is opposite that observed in the absence of impinging eddies, when the front tilts offshore as it approaches the surface. The front is extremely sharp (temperature changes of $10^{\circ} \mathrm{C}$ over $5 \mathrm{~km}$ at $50 \mathrm{~m}$ depth), and the salinity field shows signs of interleaving water masses. The influence of the Gulf Stream meander vanishes inshore of the $90 \mathrm{~m}$ isobath, where currents and water mass properties reflect normal summertime conditions over the bank crest. In contrast, ring water $(S>35.5)$ is associated with strong eastward (with a slight onshore component) currents having speeds ranging from 0.2 to $0.6 \mathrm{~m} / \mathrm{s}$, peaking where the $20^{\circ} \mathrm{C}$ isotherm intersects the surface.

\subsection{Cool Extrusion Toward Deeper Water}

[34] A section that crosses the cool extrusion shortly after it turns away from the bank (Figure 1, red "extrusion" track, and Figure 10a, magenta line) characterizes entrained bank waters and the feature's structure between the surface and
$100 \mathrm{~m}$ depth. A sharp front $\left(\Delta T=14^{\circ} \mathrm{C}\right.$ and $\Delta S=3$ over $3 \mathrm{~km})$ separates Gulf Stream meander waters $(S>35.5)$ from the cooler, less saline bank waters (Figure 13). Isopycnals tilt upward to the east (Figure 13b, contours), as might be expected from thermal wind and the observed southward shear (Figure 13b, colors). Warm, salty waters associated with the meander (Figure 13a, $x<15 \mathrm{~km}$ ) and the upper layer of cooler, fresher entrained bank waters (Figure 13a, $15 \mathrm{~km}<x<30 \mathrm{~km}$, depths shallower than $75 \mathrm{~m}$ ) flow southward, off-bank. Tracing the coolest extrusion waters $\left(T<8^{\circ} \mathrm{C}\right)$ upstream using data collected along the survey lines depicted in Figure 10a suggests that the feature draws water from the region between $66^{\circ} 30^{\prime}$ and $67^{\circ} \mathrm{W}$, though the data are insufficient to determine the precise origin (location on the bank) of the extruded waters. Extrusion waters span a range of temperatures and salinities, indicating that the extrusion draws from a range of depths and that lateral mixing with the entraining Gulf Stream meander likely modifies the exported water masses.

[35] Entrainment features of this sort have been conjectured to be a major pathway for the offshore transport of shelf waters in the Mid-Atlantic Bight [e.g., Brink, 1998], but the scarcity of well-resolved measurements and uncertainties about the features' temporal persistence have made it difficult to quantify their actual regional importance. In the present case, we estimate the outward transport of bank water $(S<33)$ to be about $7 \times 10^{4} \mathrm{~m}^{3} / \mathrm{s}$. This number can be compared to that of Joyce et al. [1992], who made well-resolved measurements of a similar feature, clearly related to a warm core ring about $100 \mathrm{~km}$ offshore of the shelf break east of Delaware Bay. Their offshore transport of 


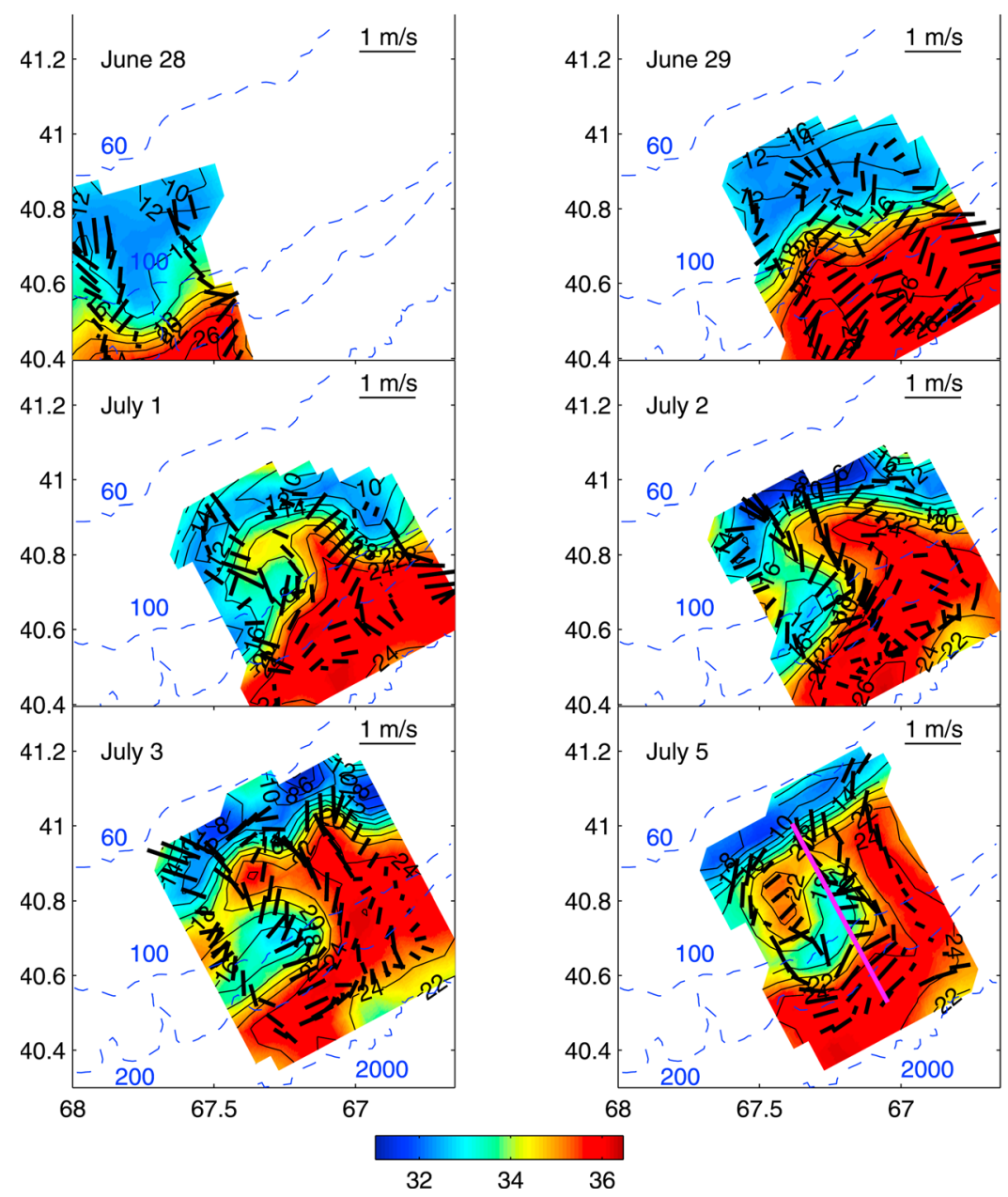

Figure 14. Time series of objectively mapped $10 \mathrm{~m}$ salinity (color), potential temperature (contours), and detided $18 \mathrm{~m}$ velocity vectors during the GLOBEC3 (summer) cruise. The magenta line in the bottom right marks the section displayed in Figure 13.

water having $S<33$ amounts to $2.2 \times 10^{4} \mathrm{~m}^{3} / \mathrm{s}$, smaller than, but the same order of magnitude as our estimate. Our measurement is thus consistent with the potential for this form of entrainment being an important sink of shelf and bank waters, although our "snapshot" measurements provide no additional information about the vexing question of the time scales over which these features act.

\subsection{Warm Intrusion Onto the Bank}

[36] Although warm core ring waters are generally thought to remain offshore of the shelf break (roughly the $100 \mathrm{~m}$ isobath [e.g., Beardsley et al., 1985]), the July 2007 encounter produces an intrusion that extends across the $100 \mathrm{~m}$ isobath, well onto the bank, and remains distinct through the 6 day measurement period (Figures 12 and 14). Ring waters move onto the shelf in a fairly narrow (roughly $20 \mathrm{~km}$ ) tongue that arcs northward and then westward to form a structure roughly $40 \mathrm{~km}$ across. The intrusion core extends slowly, around $15 \mathrm{~km} / \mathrm{d}$, compared to the greater detided speeds, up to $0.5 \mathrm{~m} / \mathrm{s}$, found within the feature. Large velocities associated with the intrusion and with the warm core ring off-bank of the $100 \mathrm{~m}$ isobath contrast with relatively stagnant (detided speeds rarely more than $0.2 \mathrm{~m} / \mathrm{s}$ ) ambient flows over the bank. Six days into the encounter, on
5 July, a $20 \mathrm{~km}$ patch of warm, high-salinity water appears to have separated from the end of the main intrusion (Figure 14), suggesting that the feature is beginning to break up. The in situ measurement program ends at this time, followed by an extended period of cloudy weather that obscures the bank from remote sensing. The intrusion's further evolution thus remains undocumented, although 25 days later (the time of the next clear AVHRR image), its surface expression has vanished.

[37] Sharp $\left(\Delta T=10^{\circ} \mathrm{C}\right.$ over $\left.10 \mathrm{~km}\right)$, on-bank tilting fronts mark the boundaries between the warm, saline ring intrusion and the cooler, fresher waters associated with the bank (Figures 12 and 15). The intrusion wraps around a core of bank water to form a sequence of fronts located at the shelf edge and at the boundaries of the intrusion itself. Over the slope, Gulf Stream meander waters $\left(T>14^{\circ} \mathrm{C}, S>35.5\right)$ occupy the upper $100 \mathrm{~m}$, while farther on-bank these waters form a $50 \mathrm{~m}$ thick surface layer atop a fresher, cooler mixture of bank and meander water. The strongest currents, with speeds approaching $0.5 \mathrm{~m} / \mathrm{s}$, extend to at least $150 \mathrm{~m}$ depth over the slope. Currents associated with the intrusion are typically somewhat weaker and more surface trapped, with little or no flow near the bottom. 

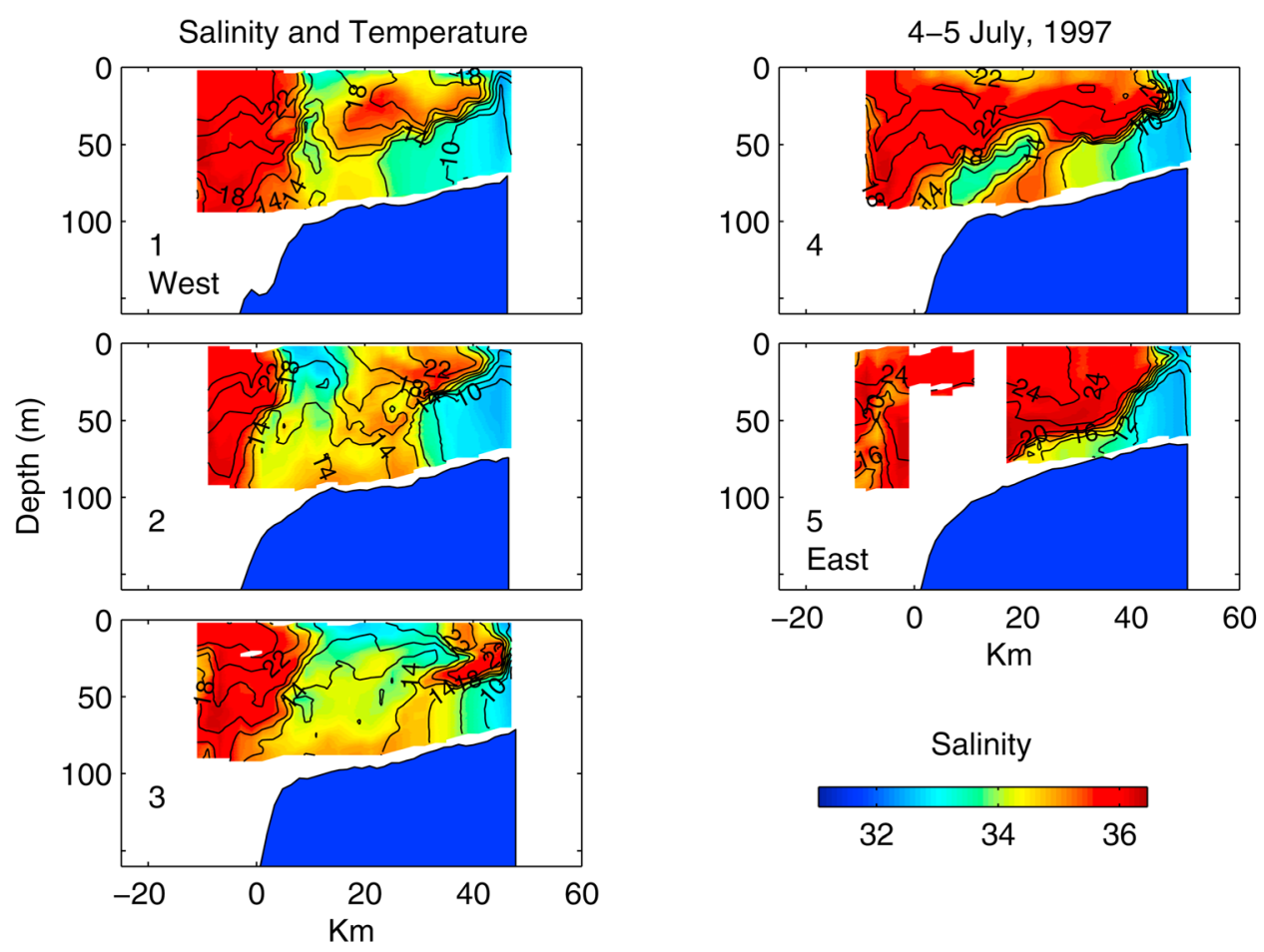

Figure 15. Individual potential temperature (contours) and salinity (color) sections from the fifth survey of the central sampling area (4-5 July 1997). The top left is the westernmost line, and the bottom right is the easternmost line. The along-isobath spacing between sections is $10 \mathrm{~km}$.

[38] If the intrusion dissipates by mixing with bank waters rather than withdrawing back across the slope to deeper water, it could represent a mechanism for transporting slope water onto the shelf. Tracers show that, on a regional scale, there has to be an onshore flux of saltier water [Chapman et al., 1986], but the mechanism for this flux is as yet unaccounted for. The impact of ring intrusions depends strongly on how frequently such events occur. On the basis of the assumptions in Brink [1998], 12-65 of these intrusions per year would be needed to provide the required onshore salt flux in the adjoining and presumably similar Mid-Atlantic Bight (west of Nantucket). This is a substantial number, and it seems unlikely that such a large number of events would go unnoted until now. It thus seems that intrusions of the sort observed here are not the main mechanism driving onshore fluxes in this region.

[39] A simple calculation involving salt content across the entire Georges Bank bounds the potential importance of intrusion-driven salinity flux. If all the feature's salty water were retained and mixed evenly across the bank, mean salinity would increase by $O(0.03)$. In practice, the dominating importance of other on-bank and off-bank fluxes (mainly along-isobath [e.g., Brink et al., 2003]) would mitigate the impact of such intrusion-driven fluxes. Specifically, much of the ring water that intrudes onto the bank would be advected alongshore onto the Mid-Atlantic Bight shelf before completing a circuit of the bank, thus reducing the intrusion-driven salinity increase on Georges Bank proper. Thus, the intrusion-driven 0.03 bank-wide salinity increase represents an extreme upper bound.

[40] It is interesting to speculate about the dynamics that allow this filament to cross the slope and intrude over the bank. The Taylor-Proudman theorem specifies that adiabatic geostrophic flows cannot cross isobaths, and this limitation seems to hold most of the time when rings encounter the shelf edge, since onshore intrusions are not commonly observed. The fact that intrusion waters are strongly stratified and thus somewhat isolated from the bottom (Figures 12 and 15) is alone not enough to break the columnar constraint [Brink, 1998]. At the on-bank edge of the ring, observed along-isobath velocity typically varies by about $0.4 \mathrm{~m} / \mathrm{s}$ over less than $20 \mathrm{~km}$, implying a Rossby number of order 0.2 and thus potentially significant ageostrophic flow. Ageostrophic dynamics admit additional effects, such as hydrodynamic instabilities at the shelf edge, that could drive eddy exchanges across local bathymetry. Likewise, at least within the intrusion (Figure 14), time variations occur quickly enough to suggest a "temporal Rossby number" (measuring time dependence relative to Coriolis terms) of 0.3 or more. Although the measurement program did not include direct measurements of mixing, the persistent, strong stratification associated with the intrusion (Figures 12 and 15 ) at least indicates that any turbulence is not strong enough to homogenize the water column. Dissipative effects (that might be measured by an Ekman number) may not be of lowest-order importance, so it is possible that the intrusion is the result of bank edge instability and that its dynamics are largely adiabatic.

[41] The Georges Bank intrusion can be compared with Gulf Stream shingles found off Georgia and the Carolinas. Shingle instabilities have similar spatial scales and are comparably surface-intensified and backswept relative to the flow in deeper water [e.g., Bane et al., 1981; Glenn and Ebbesmeyer, 1994]. One signature of shingles is the pres- 
ence of a cold dome eddy inshore of the shelf edge and about which the salty intrusion wraps. The temperature field associated with the Georges Bank feature hints at a similar doming (e.g., the $15^{\circ} \mathrm{C}$ isotherm on 2 and 3 July in Figure 14), as do the density data (not shown). The intrusion's roughly 3 day observed growth rate is similar to that reported for shingles [Miller, 1994], though the present intrusion shows no tendency for poleward alongshore propagation. With the exception of alongshore propagation, the present feature seems rather comparable to the well-studied shingles, so we tentatively conclude that, as is the case for shingles [Luther and Bane, 1985], the present intrusion is the result of a mixed barotropic-baroclinic instability near the shelf edge.

\subsection{Geostrophy During the Summer Surveys}

[42] In contrast to wintertime conditions, during summer, averaged along-isobath flow is largely geostrophic, though the degree of geostrophic balance varies widely between individual sections. For the average of 30 cross-shelf sections binned at $10 \mathrm{~km}$, mean vertical shear compares with mean thermal wind with a 0.77 correlation and a regression coefficient of 0.85 (within $95 \%$ confidence of unity). In contrast, regression coefficients for individual sections range from 0.97 to -1.46 . Inspection of individual velocity sections reveals banding with vertical wavelengths of $50-100 \mathrm{~m}$, suggesting that higher frequency motions (e.g., near-inertial or other internal waves) contribute significant ageostrophic variance. Presumably, once 30 sections are averaged together, the internal wave energy is removed, and the geostrophically balanced residual flow becomes apparent. As with the winter measurements, we conclude that instantaneous ADCP velocity data provide only a qualitative measure of the residual flow, even though the along-isobath flow is, on average, in geostrophic balance.

\section{Discussion and Conclusions}

\subsection{General}

[43] Wintertime and summertime measurement programs focused on elucidating the role of cross-frontal exchanges along the south flank of Georges Bank, with a programatic goal of understanding zooplankton and ichthyoplankton processes. A motivating hypothesis was that properly timed removals of bank waters could remove plankton and so give rise to poor year classes.

[44] Although a severe storm hindered observations, wintertime surveys characterize a crossover of Scotian Shelf waters and the impact of strong wind forcing and buoyancy forcing on this event. Prestorm and poststorm sections across the southern flank suggest that the Scotian Shelf intrusion along the bank edge became less pronounced after the storm. Advection from the bank or the Gulf of Maine cannot explain the observed freshening as upstream regions over the crest and northern flank do not exhibit waters fresh enough to account for poststorm changes. A surface-forced, one-dimensional balance can roughly account for observed changes in vertically integrated heat and salt content only in water shallower than $80 \mathrm{~m}$ over the bank, but this simple balance fails at the shelf break and farther off-bank, where advection likely dominates. Although one-dimensional processes do not dominate balances over the outer shelf and slope, observed poststorm salinities indicate that downward mixing of Scotian Shelf intrusion water must contribute to the response. Unfortunately, in the storm-shortened sampling period, surveys fail to capture other potential processes of interest, such as chronic frontal instability (as was seen, for example, by Garvine et al. [1989]), transient shelf break intrusions [e.g., Churchill et al., 2003], and separated bottom boundary layer transport [e.g., Barth et al., 2004].

[45] Summertime SeaSoar surveys captured interaction of an extreme Gulf Stream meander (that evolved into a warm core ring) with waters on the southern flank of Georges Bank, including offshore transport of bank waters in a narrow extrusion and the nearby (about $100 \mathrm{~km}$ to the west) growth of an unusual intrusion of warm core ring water onto the bank. Sections across the cold extrusion show that its waters come from over the bank, drawn from the entire water column. As suggested in previous studies [e.g., Brink, 1998], these measurements show that extrusions represent a potentially significant, though episodic, mechanism for driving off-bank transport. However, quantifying the impact of this withdrawal of shelf and bank waters requires additional measurements that resolve the frequency of these entrainment events and the time scale over which they act. The impinging warm core ring also produces an intrusion of warm, salty water that extends across the shelf break and well onto the bank. Although previous studies postulate an onshore salinity flux in this region [Chapman et al., 1986], rough calculations indicate that an implausibly large number of intrusions such as the one characterized here would be required to provide the necessary salt flux. Thus, while the intrusion represents an interesting mechanism for driving cross-shelf exchange, it may not play a leading role in the regional water mass balance.

[46] Additional conclusions can be reached by drawing on information beyond that collected through this study. Progress here requires the assumption that shelf break processes along the south flank of Georges Bank are similar to those found along the offshore edge of the Mid-Atlantic Bight. Thus, what is important in the Bight is believed to be important over the bank's southern edge. This is advantageous because Mid-Atlantic Bight shelf edge exchanges are fairly well constrained by previous current measurements and by ${ }^{18} \mathrm{O}$ and salinity data [Chapman et al., 1986; Brink, 1998]. The Mid-Atlantic Bight and the bank also differ in significant ways. Georges Bank is more biologically productive than the immediately adjoining shelf waters to the west [O'Reilly et al., 1987]. Franks and Chen [1996] attribute this enhanced productivity to tidally driven on-bank flux over the northern flank from the Gulf of Maine. This implies that the bank's high primary productivity (relative to the Mid-Atlantic Bight) does not require any unusual processes acting along its southern edge. If southern exchanges were important for bank primary productivity, one might then expect Mid-Atlantic Bight productivity to have levels comparable to those on Georges Bank, hence higher than observed.

\subsection{Off-Bank Transports}

[47] Over the $700 \mathrm{~km}$ alongshore span of the Mid-Atlantic Bight, the annual average offshore shelf water flux appears to be $0.4-1.1 \times 10^{5} \mathrm{~m}^{3} / \mathrm{s}$ [Brink, 1998]. This number must be taken with a good deal of caution, since Mountain [1991] has shown that shelf water volume is nonconservative over 
annual time scales. There are at least two strong candidates to explain the offshore transport. One is wind-driven exchange. When a northeastward wind blows, offshore Ekman transport should remove near-surface waters from the bank [e.g., Fong and Geyer, 2001]. Once the front has adjusted to this distorted condition [Ou, 1984], mixing carries shelf waters downward, producing a net off-bank flux even after the near-surface layer relaxes to its original position. Transport magnitude depends on the strength and spatial extent of the wind system: for example, the storm of February 1997 probably produced an offshore transport of order $40 \times 10^{5} \mathrm{~m}^{3} / \mathrm{s}$ for about a couple days. Ou argues that the frontal response to wind is distinctly asymmetric: that onshore Ekman transport merely steepens the front but does not give rise to the sorts of distortion that can allow (in combination with vertical mixing) cross-frontal transport. If this is the case, a mean taken over only the northeastward component of along-bank wind could provide an estimate of the net off-bank, wind-driven flux. Taking a representative Mid-Atlantic Bight 1996-1999 eastward alongshore wind stress of $0.06 \mathrm{~N} \mathrm{~m}^{-2}$ (the annual mean calculated only over times when wind stress is northeastward) produces an estimated annual mean off-bank transport of $4 \times 10^{5} \mathrm{~m}^{3} / \mathrm{s}$. This exceeds that required to explain fluxes inferred from tracer observations. Substituting an overall mean wind stress (which drives both on-bank and off-bank Ekman transport) yields $0.7 \times 10^{5} \mathrm{~m}^{3} / \mathrm{s}$, closer to the tracer-derived flux estimate but physically less sensible.

[48] Warm core rings provide another candidate for explaining offshore transport in the Mid-Atlantic Bight. The present measurements and those of Joyce et al. [1992] suggest that a warm core ring impinging on the shelf edge can transport shelf water offshore at an instantaneous rate of $0.2-0.7 \times 10^{5} \mathrm{~m}^{3} / \mathrm{s}$. On the basis of temperature and salinity properties of these features, it seems possible that this water is withdrawn from the whole shelf (or bank) water column. Using remotely sensed SST and a simple entrainment model, Chaudhuri et al. [2009] estimate that, across the entire Mid-Atlantic Bight, warm core rings drive a mean annual flux of $7.5 \times 10^{5} \mathrm{~m}^{3} / \mathrm{s}$ from shelf to deep basin, with the largest fluxes $\left(2.4 \times 10^{5} \mathrm{~m}^{3} / \mathrm{s}\right)$ occurring over Georges Bank. These figures are significantly larger that the $0.4-1.1 \times 10^{5} \mathrm{~m}^{3} / \mathrm{s}$ Mid-Atlantic Bight mean reported by Brink [1998], though Chaudhuri et al. [2009] find large interannual variations in ring-driven off-shelf transport. Given the instantaneous shelf water flux estimates for the summer 1997 event and those reported in Joyce et al. [1992], continuous entrainment by several rings through the course of a year would be required to meet even the smaller annual mean flux figure. The census of ring activity from 1978 to 1999 found in the work of Chaudhuri et al. [2009] provides a basis for quantifying the frequency of ring interactions and assessing their ability to drive the necessary off-shelf transport.

[49] Regardless of the actual withdrawal mechanism, the means of balancing the volume budget are probably similar. Specifically, when shelf water is drawn offshore, it has to come from somewhere. Since the system is unlikely to be two-dimensional, local compensation for offshore fluxes is unlikely. Instead, information about the offshore flux will propagate alongshore in the form of coastal-trapped waves, which propagate only equatorward (southwestward) in this region. This implies that, in the absence of an equatorward mean alongshore flow, the water removed originates from directly onshore or from the southwest. Since there is actually equatorward mean flow, extruded waters would likely come from upstream, though the influence of the extrusion would still be felt only equatorward. One plausible scenario is that, as wave information propagates alongshore, the required onshore transport is balanced by the shelf break front moving onshore equatorward of the extrusion. This mechanism requires a reduction in the overall volume of shelf water, but this would presumably be replaced, over time, by advection of shelf and bank water from the northeast.

[50] There are thus two credible mechanisms to explain, together or individually, estimated offshore transport in the Mid-Atlantic Bight and so, presumably, over the south flank of Georges Bank as well. Off-bank extrusion transport drawn by warm core rings impacts the entire water column and might thus prove more effective than surface-intensified wind-driven processes for transporting bottom-concentrated plankton off-bank.

\subsection{On-Bank Transports}

[51] Over the Mid-Atlantic Bight, onshore cross-frontal transport is thought to be about $0.2-0.4 \times 10^{5} \mathrm{~m}^{3} / \mathrm{s}$ [Brink, 1998]. Though the results presented above suggest that neither wind forcing nor the type of on-bank intrusion captured in the summertime surveys can produce such onshore, cross-frontal volume fluxes, other potential mechanisms warrant further evaluation.

[52] The shelf break front along Georges Bank and the Mid-Atlantic Bight is known to be chronically unstable, continually generating meanders and pinched-off eddies on the scale of 10-20 km [e.g., Garvine et al., 1989; Gawarkiewicz et al., 2004]. This process acts in the absence of warm core rings and drives exchanges with slope water rather than the even saltier ring water. Churchill et al. [2003] report salinity signatures consistent with this sort of exchange at moorings farther on-bank than sampled by SeaSoar. While it seems likely that frontal instabilities contribute to cross-frontal fluxes (both on-bank and off-bank), integrated flux estimates are rare, likely because exchange efficiency (measured by a salinity-onshore flow correlation, for example) is so low that intensive, long-term observational commitment would be required to produce robust numbers [Gawarkiewicz et al., 2004]. Though it seems likely that frontal instabilities provide a mechanism for driving substantial transport, this idea remains unconfirmed.

[53] Cross-frontal exchange might also be concentrated at a few special locations, such as submarine canyons. The mechanism for such exchange is not obvious, but it is unlikely to be associated with the geostrophic pressure gradient related to the alongshore flow (as proposed for the region off Vancouver Island by Freeland and Denman, 1982), since the mean flow in this region is in the wrong direction. Nonetheless, it is conceivable that some other mechanism, perhaps involving rectification of tidally driven up-canyon flow, might be at play.

[54] Previous studies also point to the Great South and Northeast Channels as conduits for cross-shelf exchange. An analysis of repeated hydrographic surveys (1977-1985) revealed high-salinity slope waters intruding through the 
Great South Channel in autumn of most years [Mountain et al., 1989]. Using a 2 year record of velocity and temperature from a moored array, Ramp et al. [1985] found that deep flow through the Northeast Channel produced an annual mean transport into the Gulf of Maine. Although this is not a direct on-bank flux, these waters could later enter the bank as part of the broad southward flux across the northern flank.

[55] Equally important to identifying the dominant processes driving on-bank transport is understanding whether such fluxes actually play an important role in the Georges Bank ecosystem. Cox and Wiebe [1979] make the case that expatriated warm-water species are a quantitatively important part of the outer shelf zooplankton population in the Mid-Atlantic Bight, which is likely true over Georges Bank as well. Depending on the depth from which on-bank transport draws, off-bank waters could represent a source of nutrients, thus accelerating the bank ecosystem at the level of primary production. Given the likely strength of processes that deliver nutrients across the north flank [Franks and Chen, 1996], it is probably not necessary to invoke this exchange to explain bank primary productivity, though it could be important downstream in the MidAtlantic Bight, where the tidally driven exchange is not as effective.

[56] On the basis of the observations presented here and results in the literature, this study concludes that, along the southern flank of Georges Bank, wind forcing (by northeastward winds) and warm core ring suction provide two important mechanisms for effecting off-bank transport. The latter mechanism is perhaps the more significant, because it may well draw water from the entire bank water column and so affect species, like cod, that live near the bottom. Though previous studies infer net onshore transport over the southern flank [e.g., Chapman et al., 1986], the processes that drive northward fluxes of slope water have not yet been isolated. Though striking, the observed on-bank intrusion of warm core ring water is unlikely to be the primary transport mechanism for time-averaged physical water mass properties. However, such intrusions could still be very significant in terms of zooplankton content.

[57] Acknowledgments. This work was supported by the National Science Foundation as part of the U.S. Global Ocean Ecosystems Dynamics (GLOBEC) program through grant OCE-9632349. Lee received additional support from OCE-0628379. We greatly appreciate Frank Bahr, Jerry Dean, Paul Fucile, Allan Gordon, Craig Marquette, Ellen Levy, and the captains and crews of $R / V$ Endeavor and $R / V$ Oceanus. Their dedication, skill, and hard work made this study possible. Their good humor and unflagging support made the work enjoyable. Dr. James Bisagni (School for Marine Science and Technology, University of Massachusetts) generously provided remote sensing data and assisted with advice and processing.

\section{References}

Alessi, C., et al. (2001), The 1995 Georges Bank stratification study moored array measurements, WHOI Technical Report WHOI-2001-11, Woods Hole Oceanographic Institution, Woods Hole, Mass., 106 pp.

Backus, R. H., and D. W. Bourne (1987), Georges Bank, 593 pp., MIT Press, Cambridge, Mass.

Bane, J. M., D. A. Brooks and K. R. Lorenson (1981), Synoptic observations of the three -dimensional structure and propagation of Gulf Stream meanders along the Carolina continental margin, J. Geophys. Res., 86, 6411-6425
Barth, J. A., D. Hebert, A. C. Dale, and D. S. Ullman (2004), Direct observations of along-isopycnal upwelling and diapycnal velocity at the shelf break front, J. Phys. Oceanogr., 34(3), 543-565.

Beardsley, R. C., D. C. Chapman, K. H. Brink, S. R. Ramp and R. Schlitz (1985), The Nantucket Shoals Flux Experiment (NSFE79), Part I: A basic description of the current and temperature variability, J. Phys. Oceanogr. 15, 713-748.

Beardsley, R. C., P. C. Smith and C. M. Lee (2003), Introduction to special section: U.S. GLOBEC: Physical processes on Georges Bank (GLOBEC), J. Geophys. Res., 108(C11), 8000, doi:10.1029/2003JC002165.

Bisagni, J. J., R. C. Beardsley, C. M. Ruhsam, J. P. Manning, and W. J. Williams (1996), Historical and recent evidence of Scotian Shelf Water on southern Georges Bank, Deep Sea Res. Part II, 43, 1439-1472.

Brink, K. H. (1998), Deep-sea forcing and exchange processes, in The Sea, vol. 10, edited by K. H. Brink, and A. R. Robinson, pp. 151-167, Wiley and Sons, New York.

Brink, K. H., R. Limeburner, and R. C. Beardsley (2003), Properties of flow and pressure over Georges Bank as observed with near-surface drifters, J. Geophys. Res., 108(C11), 8001, doi:10.1029/2001JC001019.

Brink, K. H., R. C. Beardsley, R. Limeburner, J. D. Irish, and M. Caruso (2009), Long-Term Moored Array Measurements of Currents and Hydrography over Georges Bank: 1994-1999, Prog. Oceanogr., 82 (2009), 191-223.

Brown, W. S., and J. A. Moody (1987), Tides, in Georges Bank, edited by R. H. Backus and D. W. Bourne, pp. 100-107, MIT Press, Cambridge, Mass.

Brown, W. S., and R. C. Beardsley (1978), Winter Circulation in the Western Gulf of Maine: Part 1. Cooling and Water Mass Formation, J. Phys. Oceanogr., 8(3), 265-277.

Chapman, D. C. (2000), Boundary layer control of buoyant coastal currents and the establishment of a shelf break front, J. Phys. Oceanogr. 30, 2941-2955.

Chapman, D. C., J. A. Barth, R. C. Beardsley, and R. G. Fairbanks (1986), On the continuity of mean flow between the Scotian Shelf and the Middle Atlantic Bight, J. Phys. Oceanogr., 16(4), 758-772.

Chaudhuri, A. H., J. J. Bisagni, and A. Gangopadhyay (2009), Shelf water entrainment by Gulf Stream warm-core rings between $75^{\circ} \mathrm{W}$ and $50^{\circ} \mathrm{W}$ during 1978-1999, Cont. Shelf Res., 29, 393-406.

Churchill, J. H., J. P. Manning, and R. C. Beardsley (2003), Slope water intrusions onto Georges Bank, J. Geophys. Res., 108(C11), 8012 doi:10.1029/2002JC001400.

Cox, J., and P. H. Wiebe (1979), Origins of oceanic plankton in the Middle Atlantic Bight, Estuarine Coastal Mar. Sci., 9, 509-527.

Firing, E., J. Ranada, and P. Caldwell (1995), Processing ADCP data with the CODAS Software System, Tech. Rep., Univ. of Hawaii, 218 pp.

Flagg, C. N. (1987), Hydrographic structure and variability, in Georges Bank, edited by R. H. Backus and D. W. Bourne, pp. 108-124, MIT Press, Cambridge, Mass.

Flagg, C. N., and M. Dunn (2003), Characterization of the mean and seasonal flow regime on Georges Bank from five years of shipboard ADCP data, J. Geophys. Res., 108(C11), 8002, doi:10.1029/2001JC001257.

Fong, D. A., and W. R. Geyer (2001), Response of a river plume during an upwelling favorable wind event, J. Geophys. Res., 106(C1), doi:10.1029/ 2000JC900134, 1067-1084.

Franks, P. J. S., and C. Chen (1996), Plankton production in tidal fronts: a model of Georges Bank in summer, J. Mar. Res., 54, 631-651.

Freeland, H. J., and K. L. Denman (1982), A topographically controlled upwelling center off southern Vancouver Island, J. Mar. Res., 40(4), 1069-1093.

Fucile, P. D. (2002), An Expendable Bioluminescence Measuring BathyPhotometer, in Proceedings of Oceans 2002 MTS/IEEE Conference, pp. 1716-1721.

Garvine, R. W., K.-C. Wong, and G. G. Gawarkiewicz (1989), Quantitative properties of shelf break eddies, J. Geophys. Res., 94(C10), 1447514483.

Gawarkiewicz, G., K. H. Brink, F. Bahr, R. C. Beardsley, M. Caruso, and J. F. Lynch (2004), A large-amplitude meander of the shelf break front south of New England: observations from the shelf break PRIMER experiment, J. Geophys. Res., 109(C3), C03006, doi:10.1029/ 2002JC001468.

Glenn, S. M., and C. C. Ebbesmeyer (1994), The structure and propagation of a Gulf Stream frontal eddy along the North Carolina shelf break, J. Geophys. Res., 99(C3), doi:10.1029/93JC02786, 5029-5046.

Joyce, T. M. (1991), Review of U.S. contributions to warm core rings, Rev. Geophys., Supplement, 610-616.

Joyce, T. M., J. K. B. Bishop, and O. B. Brown (1992), Observations of offshore shelf water transport induced by a warm-core ring, Deep Sea Res., 39(1), S97-S113. 
Large, W. G. and S. Pond (1981), Open ocean momentum flux measurements in moderate to strong winds, J. Phys. Oceanogr., 11, 324-336.

Lee, C. M., B. H. Jones, K. H. Brink, and A. S. Fischer (2000), The upperocean response to monsoonal forcing in the Arabian Sea: Seasonal and spatial variability, Deep Sea Res., Part II, 47(7-8), 1177-1226.

Lentz, S. J., R. C. Beardsley, J. D. Irish, J. Manning, P. C. Smith, and R. A. Weller (2003), Temperature and salt balances on Georges Bank FebruaryAugust, 1995, J. Geophys. Res., 108(C11), 8006, doi 10.1029/ 2001JC001220.

Loder, J. W., B. Petrie, and G. Gawarkiewicz (1998), The coastal ocean off northeastern North America: A large-scale view, in The Sea, vol. 11, The Global Coastal Ocean Regional Studies and Syntheses, edited by A. R. Robinson and K. H. Brink, pp. 105-133, John Wiley, New York.

Linder, C. A., and G. Gawarkiewicz (1998), A climatology of the shelf break front in the Middle Atlantic Bight, J. Geophys. Res., 103(C9), 98JC01438, 18,405-18,424.

Luther, M. E., and J. M. Bane (1985), Mixed instabilities in the Gulf Stream over the continental shelf, J. Phys. Oceanogr., 15, 3-23.

Manning, J. P., and G. Strout (2001), Georges Bank winds: 1975-1997, Deep Sea Res., Part II, 48, 115-135.

Miller, J. L. (1994), Fluctuations of Gulf Stream frontal position between Cape Hatteras and the Straits of Florida, J. Geophys. Res., 99(C3), doi:10.1029/93JC03484, 5057-5064.

Mountain, D. G. (1991), The volume of shelf water in the Middle Atlantic Bight: Seasonal and interannual variability, 1977-1987, Cont. Shelf Res. 11(3), 251-267.
Mountain, D. G., M. Pastuszak, and D. A. Busch (1989), Slope water intrusion to the Great South Channel during autumn, 1977-1985, J. Northwest Atl. Fish. Sci., 9, 97-102.

Ou, H. W. (1984), Wind-driven motion near a shelf-slope front, J. Phys. Oceanogr., 14(6), 985-993.

O'Reilly, J. E., C. Evans-Zetlin and D. A. Busch (1987), Primary production, in Georges Bank, edited by R. H. Backus, and D. W. Bourne, MIT Press, pp. 220-233, Cambridge, Mass.

Ramp, R. R., R. J. Schlitz and W. R. Wright (1985), The Deep Flow through the Northeast Channel, Gulf of Maine, J. Phys. Oceanogr., 15(12), 1790-1808.

Smith, P. C., C. N. Flagg, R. Limeburner, C. Fuentes-Yaco, C. Hannah R. C. Beardsley, and J. D. Irish (2003), Scotian Shelf crossovers during winter/spring 1999, J. Geophys. Res., 108(C11), 8013, doi:10.1029/ 2001JC001288.

Townsend, D. W., and A. C. Thomas (2001), Winter-spring transition of phytoplankton chlorophyll and inorganic nutrients on Georges Bank, Deep-Sea Res., Part II, 48, 199-214.

Wiebe, P., R. Beardsley, D. Mountain and A. Bucklin (2002), The U.S GLOBEC Northwest Atlantic/Georges Bank program, Oceanography, $15,13-29$.

K. H. Brink, Department of Physical Oceanography, MS-21, Woods Hole Oceanographic Institution, Woods Hole, MA 02543, USA.

C. M. Lee, Applied Physics Laboratory, Ocean Physics, University of Washington, 1013 NE 40th Street, Box 355640, Seattle, WA 98105, USA. (craig@apl.washington.edu) 